\title{
Government Access to Bank Records
}

In a highly industrialized society, second and third party institutions-banks, telephone companies, hospitals, doctors' offices, credit bureaus ${ }^{1}-$ collect and maintain an enormous quantity of personal information. ${ }^{2}$ Data which were once either nonexistent or confined solely to the individual's personal records are now reposited in files, computer discs, and microfilm beyond the individual's physical control. Statutory and common law restrictions usually govern the disclosure of this information to private parties. Yet the only effective contingency barring complete government access to these personal files is the recalcitrance of the second or third party institution. ${ }^{3}$ This

1. The term "third party" is used to describe an institution which is acting only as its customer's agent in executing transactions between the customer and another individual; the institution therefore has little or no interest in the subject matter of the underlying transaction. Examples include a telephone company in the transmission of customer telephone conversations and a bank in paying a check drawn on it by a depositor.

"Second party" describes an institution which is directly engaging in business with its customer and which is itself a party to the substantive transaction. A hospital or doctor rendering services to a patient, an attorney giving legal advice to a client, or a bank making a loan transaction would be considered acting as "second parties."

2. See generally National Academy of Sciences, Databanks in a Free Societr (1972); V. Packard, The Naked Society (1964); J. Rule, Private Lives and Public Surveillance (1973); M. WARner \& M. Stone, The Data Bank Society (1970); Karst, "The Files"; Legal Controls Over the Accuracy and Accessibility of Stored Personal Data, 31 LAw \&. Contemp. Prob. 342 (1966); notes $84-86$ infra.

3. Both Senate and House reports on the Bank Secrecy Act of Oct. 26, 1970, Pub. L. No. 91-508, 84 Stat. 1114, suggest that access to bank records is regulated. The Senate Banking Committee's report stated,

Access by law enforcement officials to bank records required to be kept under

this title would, of course, be only pursuant to a subpoena or other lawful

process as is presently the case. The legislation in no way authorizes unlimited

fishing expeditions into a bank's records on the part of law enforcement officials.

S. REP. No. 1139, 9lst Cong., 2d Sess. 5 (1970). See also H.R. REP. No. 975, 91st Cong., 2d Sess. 10, 16 (1970). The Bank Secrecy Act and the Treasury regulations thereunder have been generally thought not to have changed the government's ability to gain access to bank records. See Letter of Sec'y of the Treasury George P. Shultz, June 19, 1972, in Hearings on S.3814 \& S.3828 Before the Subcomm. on Financial Institutions of the Senate Comm. on Banking, Housing \& Urban Affairs, 92d Cong., 2d Sess. 292 (1972) [hereinafter cited as Bank Disclosure Hearings]; 31 C.F.R. $\$ 103.51$ (1973) (amended regulation effective Jan. 17, 1973). But cf. Stark v. Connally, 347 F. Supp. 1242, 1250.51 (N.D. Cal. 1972), aff'd in part, rev'd in part sub nom. California Bankers Ass'n v. Shultz, 94 S. Ct. 1494 (1974).

Disclosure of telephone conversations to government agents is restricted by statutes and the Fourth Amendment. See United States v. United States Dist. Court, 407 U.S. 297 (1972); 18 U.S.C. $\$ \$ 2510-20$ (1970). But records of long distance telephone calls are apparently fair game for government investigators. Disclosure of toll call records is not included within the prohibitions of 18 U.S.C. $\$ 2511$ (c) (1970); and 47 U.S.C. $\$ 605(1970)$ contains a broad exception which permits divulgence of information "on demand of other lawful authority." Both United States v. Covello, 410 F.2d 536, $541-42$ (2d Cir. 1969) and United States v. Russo, 250 F. Supp. 55, 59 (E.D. Pa. 1966) 
Note isolates the problem of government access to one type of third party data: checking account records maintained by commercial banks. ${ }^{4}$ It is argued that, given the purposes of the Fourth Amendment and the changes which have taken place in the nature of property and privacy, individuals should be able to contest an unreasonable search and seizure of their bank records. This Note additionally

held, without even considering the "other lawful authority" language, that Congress did not intend to prevent divulgence of toll call records to government investigators. Also, the Federal Communications Commission (FCC) recently rejected an informal proposal that it issue an order or regulation which would construe the phrase "lawful authority" to mean a subpoena, summons, or similar formal order and which would provide for notice to the telephone company's customer in the event of a governmental request for access. Letter from Kelley E. Griffith, Chief, FCC Domestic Rates Div., to William Olds, Executive Director, Conn. Civil Liberties Union, Aug. 17, 1973 (FCC letter \#9310). However, after a formal complaint on the matter was filed with the FCC by the Connecticut Civil Liberties Union against Southern New England Telephone Company, the company announced that, "Effective March 1, no Bell System telephone company will turn over customer long distance records to government or law enforcement agencies or legislative committees except under subpoena or administrative summons." Southern New England Tel. Co. Press Release, Feb. 15, 1974, at 1. See also Conn. Civil Liberties Union News, Feb. 1974, at 1, col. 3.

By negative implication $\$ 1681 f$ of the Fair Credit Reporting Act, 15 U.S.C. $\$ \$ 1681-81 \mathrm{t}$ (1970), would seem to prohibit credit reporting bureaus from disclosing all but a limited type of information to government agents. However, investigators might attempt to avail themselves of the exceptions of $\$ \$ 1681 \mathrm{~b}(3)(\mathrm{D})$ and (E) of the Act through a broad interpretation of phrases which authorize disclosure in connection with a "benefit granted by a governmental instrumentality" on "legitimate business ... [in the context of] a business transaction." The government could also advance the argument that, despite its literal import, the Act was designed primarily to prevent the misuse of information by private parties and was not intended to bar a dis. closure to government agents involved in legitimate criminal and tax investigations; cf. United States v. Russo, 250 F. Supp. 55, 59 (E.D. Pa. 1966). Government access to credit agency files has been unlicensed in years past. See Bank Disclosure Hearings, supra, at 1475; Note, Protecting the Subjects of Credit Reports, 80 YaLE L.J. 1035, $1039-40$ (1971).

Hospitals reportedly have strict rules controlling the release of medical data to govcrnment officials, see National ACAdemy of ScIences, supra note 2, at 148, but security is often weak, $i d$. at 204. With the cooperation of private insurance companies, government agents may also be able to gain access to large medical data banks. See Hearings on $S .2360$ Before the Subcomm. on Consumer Credit of the Senate Comm. on Banking, Housing \& Urban Affairs, 93d Cong., lst Sess. 442 (1973).

4. Commercial banks today engage in a myriad of customer services, each of which generates records. This Note focuses only on checking accounts for several reasons. First, checking accounts have a long history of customer secrecy. The litigation cancerning unauthorized disclosure of account information has been confined to release of checking account information. See pp. 1463-64 infra. Second, cancelled checks and deposit slips are the type of records most frequently sought by government investigators, since they provide documentary proof of the depositor's activities with other individuals. See the case histories described in Bank Disclosure Hearings, supra note 3, at 93-98. Third, in processing checks, banks function most clearly as passive intermediaries, without any interest in the underlying fund transfers other than verification that the instrument is valid and properly negotiated. This status as payments-transfer intermediary distinguishes the commercial bank from other financial institutions. In contrast, a bank engaging in a loan transaction is a creditor, as to whom such a strict duty of secrecy may not apply. See United States v. Cleveland Trust Co., 474 F.2d 1234, 1235 (6th Cir. 1973) (financial data submitted to bank in loan application not subject to constitutional protection). Unless otherwise noted the term "bank records" will be used to refer only to bank documents pertaining to checking accounts. 
maintains that banks ordinarily lack authority to consent to a government search of depositors' records.

\section{The Conflict Between Depositor Privacy and Government Access to Bank Records}

Access to bank records facilitates government investigationswhether the inquiry is legitimate or not. ${ }^{5}$ Bank data reveal more than credit-worthiness, wealth, and income. Records which list dates, payees, payors, and other memoranda can be used to reconstruct an accurate profile of an individual's activities, habits, and even intimate personal affairs. ${ }^{6}$ In years past some bankers have cooperated with federal agents by informally providing information concerning their depositors' transactions. ${ }^{7}$ These judicially unsupervised inspections of depositors' accounts have resulted in serious and possibly widespread abuses, particularly in the form of government surveillance of po. litically dissident individuals. ${ }^{8}$

Several factors exacerbate the problem of government access. The amount of information retained by financial institutions in their ordinary course of business has greatly increased. ${ }^{9}$ If banks were not already recording virtually every aspect of their depositors' transactions, they were forced to do so by the Bank Secrecy Act ${ }^{10}$ and Treasury regulations ${ }^{11}$ thereunder. Furthermore, the development of an

5. Government investigators have strongly emphasized their need for bank information. See Bank Disclosure Hearings, supra note 3, at 41-60, 106-22; Hearings on H.R. 15073 Before the House Conm. on Banking and Currency, 91st Cong, 1st \& 2d Sess. 10-180 (1969-70) [hereinafter cited as Secrecy Act Hearings.]

6. See, e.g., California Bankers Ass'n v. Shultz, 94 S. Ct. 1494, 1526 (1974) (Powell, J., concurring); id. at 1529 (Douglas, J., dissenting); Bank Disclosure Hearings, supra note 3 , at 176 .

7. See California Bankers Ass'n v. Shultz, 94 S. Ct. 1494, 1534-35 (1974) (Marshall, J., dissenting). Bank cooperation was present in the case histories described by the Treasury Department in the Bank Disclosure Hearings, supra note 3, at 93-98, 104. See also Secrecy Act Hearings, supra note 5, at 312-73.

8. A number of incidents were discussed in Bank Disclosure Hearings, supra note 3 , at $135-43,164-75,176-77$. After producing evidence concerning FBI surveillance of the checking accounts of Jane Fonda, Floyd McKissick, and Benjamin Spock, columnist Jack Anderson stated, "[T] he F.B.I. has been nosing into private bank accounts for years, with the full cooperation of bank executives." Id. at 137-38. See also Address by John Shattuck before the N.Y. State Bar Ass'n, Jan. 25, 1973, at 4 n.l.

9. See note 103 infra.

10. Act of Oct. 26, 1970, Pub. L. No. 91-508, 84 Stat. 1114 [hereinafter cited as Bank Sccrecy Act]. The Bank Secrecy Act is codified in 12 U.S.C. $\$ 1829 \mathrm{~b}$ (1970) (retention of records by insured banks); id. $\$ 1730 d$ (retention of records of savings and loan institutions insured by the Federal Savings \& Loan Ins. Corp.); id. $\$ \$ 1951-59$ (retention of records by all noninsured financial institutions); and 31 U.S.C. $\$ \$ 1051-1122$ (1970) (reporting of domestic and foreign currency transactions).

11. 31 C.F.R. $\$ 103$ (1973). See note 52 infra for a description of the recordkeeping requirements. These recordkeeping requirements were upheld against constitutional attack in California Bankers Ass'n v. Shultz, 94 S. Ct. 1494 (1974). 
electronic funds transfer system ${ }^{12}$ in lieu of current paper check payments will provide more information concerning depositors' transactions ${ }^{13}$ and will place the data in a readily accessible and usable form..$^{14}$ The ability to retrieve quickly information concerning individuals' payments and receipts creates the specter of computerized searches of thousands of accounts for specified funds transfers. In light of the massive recordkeeping of personal financial transactions, unrestricted government access to bank records poses a severe threat to civil liberties and privacy. ${ }^{15}$

12. A description of the operations of electronic banking and a survey of the legal problems it engenders can be found in LEGAL AND REGULATORY IsSUES OF ELECTRONIC Funds Transfer Systems and New Payment Services, Reistad Research Report No. 7, Feb. 1973 (Payment Systems, Inc., N.Y.C.); Bus. WEEk, Sept. 15, 1973, at 116-24; Note, Toward a Less Check Society, 47 NoTre DaMe Law. 1163 (1972). A bibliography can be found in Hearings Pursuant to S. Res. 25 Before the Subcomm. on Administrative Practice and Procedure of the Senate Comm. on the Judiciary, 90th Cong., 2d Sess., pt. 2, at 353 (1968).

13. For example, some plans for electronic funds transfer system (EFTS) envision that, when point-of-sale transfers of funds are made (see Bus. WEek, supra note 12 , at 117), a different code would be used on the depositor's monthly statement to differentiate the transaction from a preauthorized payment or payments made at the bank. The whereabouts of the depositor could be reconstructed by examining his bank statement and following the point-of-sale transactions made. Interview with Dale Reistad, Pres. of Payment Systems, Inc., in New York City, Aug. 31, 1973.

14. Checks are usually microfilmed in batches received rather than by individual account. Interview with Robert Glazer, Zone Sales Manager of Microimagery Div. of Bell \& Howell, in New York City, Feb. 21, 1974. While one check may be located relatively quickly, many hours may be needed to retrieve all copies of an account's cancelled checks in order to reconstruct a depositor's activities, particularly if the bank has adopted an inefficient indexing or storage system. See, e.g., the investigative difficulties described in United States v. Northwest Pa. Bank \& Trust Co., 355 F. Supp. 607, 610-11, 614 (W.D. Pa. 1973). See also Secrecy Act Hearings, supra note 5, at 351-57. Under EFTS entries to an account would probably be stored together.

15. The problem has not gone unrecognized. In 1972 legislation was introduced in Congress to limit the disclosure of bank information. H.R. 16246, 92d Cong., 2d Sess. (1972); S.3828, 92d Cong., 2d Sess. (1972); S.3814, 92d Cong., 2d Sess. (1972). Hearings were held (Bank Disclosure Hearings, supra note 3), but no subsequent action was taken. Similar bills are currently pending before Congress. H.R. 8062, 93d Cong., lst Sess. (1973); H.R. 9563, 93d Cong., Ist Sess. (1973); S.2200, 93d Cong., Ist Sess. (1973).

Shortly before Treasury regulations were issued under the Bank Secrecy Act, a suit was instituted in the Northern District of California to enjoin the recordkecping and reporting requirements of the Treasury regulations. See Stark v. Connally, 347 F. Supp. 1242 (N.D. Cal. 1972), aff'd in part, rev'd in part sub nom. California Bankers Ass'n v. Shultz, 94 S. Ct. 1494 (1974). The three-judge district court unanimously upheld the recordkeeping requirements, but with one dissent declared the domestic currency reporting provisions invalid. See generally 51 TexAs L. REv. 602 (1973). The Supreme Court sustained the Act and regulations in their entirety.

Recently, many banks have adopted more restrictive policies toward government inquiries. The American Civil Liberties Union has proposed a depositor contract which provides for bank notification of the customer if attempts are made to summon his records and prohibits the release of bank information absent depositor consent or a judicially enforced subpoena. See Civil Liberties, Oct. 1972, at 3. A number of bank associations have by resolution adopted the principles set forth in the proposal. Telephone Interview with John Shattuck, N.Y. Office of the Am. Civil Liberties Union, Feb. 6, 1974. See also Memorandum from Bud King of Conn. Bankers Ass'n to chief executive officers of Conn. banks, Oct. 10, 1972. Fifty-eight banks responding to a statewide survey of Connecticut banks stated that they had adopted restrictive policies on government access. Conn. Civil Liberties Union News, Feb. 1974, at 1, col. 1 . 


\section{Property Concepts and the Fourth Amendment}

While a number of ad hoc legal doctrines might be utilized to secure the bank depositor's privacy, ${ }^{16}$ the most significant legal ${ }^{17}$ guarantee of freedom from government intrusion is the Fourth Amendment. ${ }^{18}$ However, application of the Fourth Amendment to depositors'

16. Government acquisition of bank records could conceivably be limited on the theory that financial information is inherently "private" and therefore deserving of constitutional protection under a broad "right to privacy." However, constitutional protection of information and activities per se as "private" has thus far been confined to sexual matters. A standard of cultural revulsion seems to mark the boundaries of the "right to privacy." Since revelation of a financial payment, even though the payment is accompanied by an "expectation of privacy," hardly evokes the same shock and dismay as does an invasion of marital bedroom, protection for bank records would under this privacy theory be unlikely. Nonetheless, exposure of a large number of transactions together in a form which reveals underlying modes and habits of living may sufficiently offend the senses as to generate a Griswold privacy right for financial affairs; cf. Griswold v. Connecticut, 381 U.S. 479 (1965). The Supreme Court, however, has yet to adopt protective safeguards for privacy based upon such an informational metamorphosis. And, except in extreme instances that involve political surveillance, the government usually examines bank data only to locate certain types of payments or to identify relatively specific behavioral patterns. See, e.g., Bank Disclosure Hearings, supra note 3 , at $93-98$.

It should also be noted that some courts have indirectly questioned the existence of any confidentiality or privacy for negotiable payments. "[These] items were negotiable instruments in commerce and were never confidential from the time of their creation." United States v. Judson, 322 F.2d 460, 463 (9th Cir. 1963). See also Harris v. United States, 413 F.2d 316, 319-20 (9th Cir. 1969). But cf. City of Carmel-by-the-Sea v. Young, 2 Cal. 3d 259, 268, 466 P.2d 225, 231-32, 85 Cal. Rptr. 1, 7-8 (1970) (statute requiring public officials to disclose all personal financial investments in excess of $\$ 10,000$ held unconstitutional on, among other grounds, a right to privacy).

The First Amendment protects bank records where their divulgence would harm the exercise of political rights. The Supreme Court has recognized a First Amendment right to privacy of association on several occasions, although not in the context of bank records. See, e.g., Gibson v. Florida Legislative Comm., 372 U.S. 539 (1963); Louisiana ex rel. Gremillion v. N.AACP, 366 U.S. 293 (1961); Bates v. Little Rock, 361 U.S. 516 (1960); NAACP v. Alabama, 357 U.S. 449 (1958). See also Note, Privacy in the First Amendment, 82 YALE L.J. 1462 (1973).

Two federal courts have quashed government subpoenas for bank records on First Amendment grounds. United States Servicemen's Fund v. Eastland, 488 F.2d 1252 (D.C. Cir. 1973); Pollard v. Roberts, 283 F. Supp. 248 (E.D. Ark.), aff'd per curiam, 393 U.S. 14 (1968). Both cases concerned records of contributions to political groups. Also, bank records on proper occasion may be subject to protection when the at-
torney-client privilege applies, Donaldson v. United States, 400 U.S. 517, 530 (1971); Reisman v. Caplin, 375 U.S. 440,449 (1964), or when judicial process is abused, see
note 17 infra.

17. As a practical matter notice of an impending investigation accompanied by cooperation of the third party record holder will usually prevent an unreasonable search. If the government is required to obtain a judicial order enforcing its informal demand or summons, the motives and purposes of the search may be exposed, inviting judicial scrutiny, even in the absence of the litigant's "standing" to contest
the subpoena.

It is the court's process which is invoked to enforce the administrative summons and a court may not permit its process to be abused. Such an abuse would take place if the summons had been issued for an improper purpose... or for any other purpose reflecting on the good faith of the particular investigation.

United States v. Powell, 379 U.S. 48, 58 (1964).

However, the most serious threats to civil liberties are likely to occur when records are sought extrajudicially without issuance of notice to the affected individual.

18. The right of the people to be secure in their persons, houses, papers, and effects, against unreasonable searches and seizures, shall not be violated, and no 
interests in bank records encounters doctrinal difficulties. The basic problem is whether depositors have a Fourth Amendment interest in their checking account records maintained by a commercial bank, i.e., whether such records are within the set of objects and areas whose search or seizure the individual can protest under the Fourth Amendment. Individual $X$ can clearly object under the Fourth Amendment to an unreasonable search of his own home; but $X$ is not protected against a search-reasonable or unreasonable-of the house of his neighbor $Y .^{19} \mathrm{X}$ has no Fourth Amendment interest ${ }^{20}$ in $Y$ 's house. Of course, $X$ 's Fourth Amendment interest in his own house does not protect $X$ against all government intrusions into his home: Reasonable searches, such as those pursuant to a valid warrant, are permissible. But unless $X$ has a Fourth Amendment interest in the object seized or area searched, he lacks the prerequisites for a claim to relief.

Although individuals certainly consider their bank records to be private, and although the Fourth Amendment has long been associated with privacy, ${ }^{21}$. the Amendment's protections are phrased largely in terms of property: "the right of the people to be secure in their per-

warrants shall issue, but upon probable cause, supported by oath or affirmation, and particularly describing the place to be searched, and the persons or things to be seized.

U.S. Const. amend. IV.

19. Federal and state courts have steadfastly prevented the assertion of jus tertii claims under the Fourth Amendment. See, e.g., Alderman v. United States, 394 U.S. $165,171-76$ (1969). For a discussion of the unique California rule announced in People v. Martin, 45 Cal. 2d 755, 290 P.2d 855 (1955), which allows the assertion of jus tertii claims, see Note, The Vicarious Exclusionary Rule in California, 24 STAN. L. REv. 947 (1972). But see Kaplan v. Superior Court, 15 Cal. App. 3d 785, 93 Cal. Rptr. 482 (1971). See also Model Code of Pre-Arraignment Procedure $\$ 8.01(5) \&$ Commentary at 104.05 (Tent. Draft No. 3, 1970); White \& Greenspan, Standing to Object to Search and Seizure, 118 U. PA. L. REv. 333 (1970); Note, Standing to Object to an Unreasonable Search and Seizure, 34 U. CHI. L. REv. 342 (1967).

20. The term "Fourth Amendment interest" will be used in this Note in lieu of the frequently misapplied term "standing." See Albert, Standing to Challenge Administrative Action: An Inadequate Surrogate for Claims for Relief, 82 YALE L.J. 425, 427-42 (1974). Standing in search and seizure cases has often been given a broad meaning to include three concepts: the constitutional need for a case or controversy; jus tertii claims made by those not the direct victims of searches; and the class of objects and areas which the individual can claim are protected directly under his Fourth Amendment rights, i.e., those objects in which he has a Fourth Amendment interest. See generally id. at 427-28, 465-72. Only the last aspect of "standing" is con= sidered in this Note. However, courts often employ the broad term "standing" when referring to the narrower meaning used here. See, e.g., United States v. Silverman, 449 F.2d 1341 (2d Cir. 1971); SEC v. First Security Bank, 447 F.2d 166 (10th Cir. 1971). Although not usually found in the Fourth Amendment area, the "case or controversy" aspect of "standing" was present in California Bankers Ass'n v. Shultz, 94 S. Ct. 1494, 1520-25 (1974). There plaintiff bank' failure to allege participation in transactions which under the Bank Secrecy Act must be reported prevented any "case or controversy" from arising over the banks' challenge to those reporting requirements.

21. See, e.g., Berger v. New York, 388 U.S. 41, 53 (1967); Wolf v. Colorado, 338 U.S. 25, 27 (1949) (overruled on other grounds by Mapp v. Ohio, 367 U.S. 643 (1961)); Olmstead v. United States, 277 U.S. 438, 478.79 (Brandeis \& Holmes, JJ., dissenting) (1928); Boyd v. United States, 116 U.S. 616,630 (1886). 
sons, houses, papers, and effects . . . "Traditionally, lower federal courts $^{22}$ read the Amendment in its most literal sense; they equated Fourth Amendment interests with property interests. ${ }^{23}$ Under this proprietary standard an individual is protected by the Fourth Amendment against an unreasonable search of an area if he has an ownership or possessory interest in the premises, ${ }^{24}$ or, under recent decisions, if he lawfully occupies the premises at the time of the search. ${ }^{25} \mathrm{An}$ individual's protection against unreasonable seizure of his "papers and effects" has never been fully clarified. An early line of cases, mostly in the Second Circuit, held that only one in possession of "papers and effects" could complain of their seizure. ${ }^{26}$ However, the prevalent view, dating back to dictum of Justice Field in $1878,{ }^{27}$ is that ownership of property alone gives an individual a sufficient interest to contest a seizure, without regard to possession. ${ }^{28}$ Either possession or

22. Prior to United States v. Jeffers, 342 U.S. 48 (1951), the Supreme Court had never cxpressly dealt with the bounds of the individual's Fourth Amendment interests in objects seized. See Goldstein v. United States, 316 U.S. 114, 121 (1942); Annot., 96 L.Ed. 66, 67 (1952).

23. See, e.g., Cravens v. United States, 62 F.2d 261, 266 (8th Cir. 1933). See also Dutile, Some Observations on the Supreme Court's Use of Property Concepts in Resolving Fourth Amendment Problems, 21 CATH. U.L. REv. 1, 27-33 (1971); Weeks, Standing to Object in the Field of Search and Seizure, 6 ARIz. L. REv. 65 (1964).

24. See Alderman v. United States, 394 U.S. 165, 176-77 (1969); Jones v. United States, 362 U.S. 257, 266 (1960); Johnson v. United States, 333 U.S. 10 (1948); Grainger v. United States, 158 F.2d 236 (4th Cir. 1946); MacDaniel v. United States, 294 F. 768, 771 (6th Cir.), cert. denied, 264 U.S. 593 (1924).

25. See Mancusi v. DeForte, 392 U.S. 364 (1968) (employee in business office allowed to contest illegal seizure of employer's records from that office).

26. See United States v. Walker, 190 F.2d 481, 483 (2d Cir. 1951); United States v. Ebeling, 146 F.2d 254, 257 (2d Cir. 1944); United States v. Reiburn, 127 F.2d 525, 526 (2d Cir. 1942); United States v. Printing Mach., 122 F.2d 764 (3d Cir. 1941); McMann v. SEC, 87 F.2d 377, 379 (2d Cir.), cert. denied, 301 U.S. 684 (1937) (lack of possession mentioned in dictum); United States v. Hoyt, 53 F.2d 881, 885 (S.D.N.Y. 1931); United States v. Kaplan, 286 F. 963, 969 (S.D. Ga. 1923); cf. Schwimmer v. United States, 232 F.2d 855 (8th Cir. 1956). The position adopted by the cases re. quiring possession can be criticized as reducing the "papers and effects" phrase in the Fourth Amendment to surplusage. The "persons" and "houses" provisions con. ceivably already provide Fourth Amendment coverage for documents in instances where the individual has possession of those documents.

27. Letters and sealed packages . . . in the mail are as fully guarded from examination and inspection... as if they were retained by the parties forwarding them in their own domiciles. The constitutional guaranty of the right of the people to be secure in their papers against unreasonable searches and seizures extends to their papers, thus closed against inspection, wherever they may be.

Ex parte Jackson, 96 U.S. 727, 733 (1878).

28. See United States v. West, 453 F.2d 1351, 1355-56 (3d Cir. 1972); Jeffers v. United States, 187 F.2d 498 (D.C. Cir. 1950), aff'd, 342 U.S. 48 (1951); Pielow v. United States, 8 F.2d 492, 493 (9th Cir. 1925); United States v. Elkins, 195 F. Supp. 757, 759 (D. Ore. 1961); United States v. Lester, 21 F.R.D. 376, 381 (W.D. Pa. 1957); United States v. Fowler, 17 F.R.D. 499, 502 (S.D. Cal. 1955); United States v. Pete, 11 I F. Supp. 292, 293 (D.D.C. 1953). Several recent circuit court decisions have reached the merits of seizures of goods not possessed by defendants, perhaps implicitly assuming that owners of seized goods have a Fourth Amendment interest even when not in possession of those goods. See United States v. Echols, 477 F.2d 37 (8th Cir. 
ownership, however, was a prerequisite to assertion of a Fourth Amendment claim.

\section{A. A Traditional Approach: A Property Test Applied to Bank Records}

The overwhelming majority of lower federal courts, by stating that the relevant documents are the bank's property and that the depositor has no proprietary interest, have denied "standing" (i.e., a Fourth Amendment interest) to depositors contesting a search or seizure of their checking account records. ${ }^{29}$ The statement from In re Upham's Income Tax is typical:

The summons were on the bank to produce papers belonging to the bank and in its possession. The Fourth Amendment does not guarantee to a person security against search, reasonable or unreasonable, in papers which are not that person's property and are not in his possession. ${ }^{30}$

The harshness of this proprietary interest doctrine is apparent. Despite the existence of a confidential relationship between the bank and its checking account depositors, bank records become indistin-

1973); United States v. Harding, 475 F.2d 480 (10th Cir. 1973); Corngold v. United States, 367 F.2d 1 (9th Cir. 1966); United States v. Averell, 296 F. Supp. 1004 (E.D.N.Y. 1969).

The Supreme Court has never expressly ruled on the issue, but several opinions indicate that ownership alone is sufficient. See Brown v. United States, 411 U.S. 223, 230 n.4 (1973); Alderman v. United States, 394 U.S. 165,179 n.11 (1969). See also Frazier v. Cupp, 394 U.S. 731, 740 (1969); Simmons v. United States, 390 U.S. 377, 391 (1968); Jeffers v. United States, 342 U.S. 48 (1951) (Court refused to consider search of apartment separate from seizure of defendant's goods, where apartment was not residence of defendant, but as to which he had a key and free access).

But note that, if possession is relinquished and protected objects are placed wherc they are easily accessible to unauthorized persons (such as on a sidewalk or in an open area, the claimant may be considered to have implicitly consented to a search and seizure), thereby relinquishing his Fourth Amendment interest. See pp. 1467-68 infra.

29. See Harris v. United States, 413 F.2d 316, 318 (9th Cir. 1969); Galbraith v. United States, 387 F.2d 617, 618-19 (10th Cir. 1968); O'Donnell v. Sullivan, 364 F.2d 43, 44 (1st Cir.), cert. denied, 385 U.S. 969 (1966); In re Cole, 342 F.2d 5, 8 (2d Cir.), cert. denied, 381 U.S. 950 (1965); DeMasters v. Arend, 313 F.2d 79, 85 (9th Cir.) petition for cert. dismissed, 375 U.S. 936 (1963); Foster v. United States, 265 F.2d 183, $187-88$ (2d Cir.), cert. denied, 360 U.S. 912 (1959); United States v. Peoples Deposit Bank \& Trust Co., 112 F. Supp. 720, 723-24 (E.D. Ky. 1953) aff'd, 212 F.2d 86 (6th Cir.), cert. denied, 348 U.S. 838 (1954); In re Üpham's Income Tax, 18 F. Supp. 737, 738 (S.D.N.Y. I937); Cooley v. Bergin, 27 F.2d 930, 933 (D. Mass. 1928); cf. Pollard v. Roberts, 283 F. Supp. 248, 258-59 (E.D. Ark.), aff'd per curiam, 393 U.S. 14 (1968). But cf. United States v. Bank of Commerce, 405 F.2d 931, 933 (3d Cir. 1969); Stark v. Connally, 347 F. Supp. 1242, $1248-49$ (N.D. Cal. 1972), aff'd in part, rev'd in part sub nom. California Bankers Ass'n v. Shultz, 94 S. Ct. 1494 (1974). See also Zimmerman v. Wilson, 105 F.2d 583, 586 (3d Cir. 1939); McMann v. SEC, 87 F.2d 377, 379 (2d Cir.), cert. denied, 301 U.S. 684 (1937).

30. 18 F. Supp. 737, 738 (S.D.N.Y. 1937). 
guishable from the papers of other witnesses for purposes of the Fourth Amendment. ${ }^{31}$ Since bank records are generally not owned by the depositor, strict application of the proprietary interest test denies Fourth Amendment protection even if the government steals or fraudulently obtains the documents.

Although the Supreme Court clearly sustained the validity of bank recordkeeping in California Bankers Association v. Shultz ${ }^{32}$ and has previously upheld the constitutionality of administrative subpoenas, ${ }^{33}$ the Court has never considered a depositor's right to contest a search or subpoena of his bank records. ${ }^{34}$ In Donaldson $v$. United States, ${ }^{35}$ however, the Court arguably adopted a proprietary interest test for determining Fourth Amendment interests in an analogous third party record situation. Donaldson denied a taxpayer's attempt to intervene as of right in a proceeding brought to enforce an Internal Revenue Service (IRS) summons directed to the taxpayer's former employer ordering production of records of salary payments and other transactions with the taxpayer. ${ }^{36}$ The case was principally concerned with

31. Absent special circumstances such as an attorney-client privilege, individuals have no grounds to contest the seizure-unreasonable or not-of papers belonging to a third party such as a witness. The absence of a Fourth Amendment interest and the inability to assert jus tertii claims precludes any grounds for objection. See DeMasters v. Arend, 313 F.2d 79, 85 n.11 (9th Cir.), petition for cert. dismissed, 375 U.S. 936 (1963); note 19 supra. The relationship between a bank and its depositors is not sub. ject to an evidentiary privilege. See Harris v. United States, 413 F.2d 316, 319-20 (9th Cir. 1969).

32. 94 S. Ct. 1494 (1974)

33. See Oklahoma Press Publishing Co. v. Walling, 327 U.S. 186 (1946); United States v. First Nat'l Bank of Mobile, 267 U.S. 576 (1925), aff'g per curiam, 295 F. 142 (S.D. Ala. 1924).

34. In United States v. First Nat'l Bank of Mobile, 267 U.S. 576 (1925) no depositors' claims were presented: The bank itself was contesting the constitutionality of the enforcement of administrative summons. In California Bankers Ass'n v. Shultz, 94 S. Ct. 1494 (1974), the Court apparently concluded that the depositor's Fourth Amendment objections were premature. See note 59 infra.

35. 400 U.S. 517 (1971).

36. Donaldson, a rather complex case, consists of several basic holdings. First, the case primarily decides that a taxpayer may not intervene as of right under FED. $R$. Civ. P. 24(a)(2) in a proceeding to enforce an IRS summons merely because his tax liability is the underlying subject of the summons. Id. at 527-30. The taxpayer must demonstrate some "significantly protectable interest" to intervene as of right. Id. at 531. Second, the Court determined that the taxpayer Donaldson lacked such a significantly protectable interest, and in doing so stated that the taxpayer had no "proprietary interest" in the records which would allow him to intervene. Id. at 530-31. It is the implications of this second holding which are relevant to this Note. Third, the Court stated that even though the taxpayer could not intervene as of right, a court may allow permissive intervention where the taxpayer asserts abuse of process claims or claims that a summons is being used for an improper purpose. Id. at 529, 531. The Court noted that even if such intervention is disallowed, the taxpayer could assert his claims at a later time if the government attempts to use evidence gathered wrongfully in a subsequent trial. And finally, the opinion discusses the use of administrative summonses for investigations in which criminal prosecution may result. It holds that dictum in Reisman v. Caplin, 375 U.S. 440 , 449 (1964), prohibits at most the use of summonses in "an investigation solely for criminal purposes." 
the requisites of intervention under the Federal Rules of Civil Procedure and not with the Fourth Amendment. However, in distinguishing those objects in third party hands in which Fourth Amendment protection might be extended, the Court stated that the corporate records sought were "records in which the taxpayer has no proprietary interest of any kind, which are owned by the third person, which are in his hands, and which relate to the third person's business transactions with the taxpayer." 37 This language seems to suggest that a proprietary interest in documents is necessary to assert Fourth Amendment objections to any seizure, summons, or subpoena of the records. ${ }^{38}$ Several lower court cases following Donaldson have apparently so read the opinion and have used a proprietary interest test to deny bank depositors' intervention in summons enforcement proceedings, thus impliedly holding that depositors without proprietary interests also have no Fourth Amendment claims. ${ }^{39}$

While this interpretation of Donaldson is certainly plausible, two caveats must be entered. When it spoke of "proprietary interest," the Court may have been referring only to intervention rights under Rule $24(a)(2)^{40}$ and not to the Fourth Amendment. The opinion stated

37. 400 U.S. at 530 .

38. Viewed in this manner, the Donaldson Court adopts the position set out in the Brief for the United States at 16-19, id. The government there argucd that only two types of "interests" would allow taxpayers to intervene: proprietary interests and claims of evidentiary privilege. Implicitly, if these are the only types of "significantly protectable interests," then no Fourth Amendment claims could exist outside the bounds of proprietary interest or evidentiary privilege. Since bank depositors have neither, they would therefore have no Fourth Amendment interest. This reading of Donaldson is buttressed by the Court's disapproval of lower court decisions which allowed bank depositors to intervene in proceedings to enforce summonses issued to their banks (and conversely approved holdings which had not permitted intervention). See 400 U.S. at 530; United States v. Benford, 406 F.2d 1192, 1194 (7th Cir. 1969); United States v. Bank of Commerce, 405 F.2d 931, 933 (3d Cir. 1969); Justice v. United States, 365 F.2d 312, 314 (6th Cir. 1966). The two lower court opinions approved by Donaldson, O'Donnell v. Sullivan, 364 F.2d 43, 44 (Ist Cir.), cert. denied, 385 U.S. 969 (1966) and In re Cole, 342 F.2d 5, 7-8 (2d Cir.), cert. denied, 381 U.S. 950 (1965), utilized a proprietary interest test to prevent depositors from asserting rights in their bank's records.

39. See United States v. National State Bank, 454 F.2d 1249, 1251 n.3, 1252 (7th Cir. 1972); SEC v. First Security Bank, 447 F.2d 166, 168 (10th Cir. 1968); United States v. Bremicker, 365 F. Supp. 701, 702-03 (D. Minn. 1973); United States v. Union Nat'l Bank, 363 F. Supp. 629, 631-33 (W.D. Pa. 1973); United States v. Northwest Pa. Bank \& Trust Co., 355 F. Supp. 607, 612, 614 (W.D. Pa. 1973); Smith v. Switzer, 73-2 U.S. Tax Cas. If 9490 (W.D. Pa, May 30, 1973). See also United States v. Luther, 481 F.2d 429, 433 (9th Gir. 1973) (taxpayer lacked proprietary interest in corporate rccords); United States v. Weingarden, 473 F.2d 454, 458 n.4 (6th Cir. 1973) (taxpayer had no proprietary interest in attorney's records); United States v. Widelski, 452 F.2d 1, 4 (6th Cir. 1971) (no proprietary interest or privilege in accountant's records); cf. Fifth Ave. Peace Parade Comm. v. Gray, 480 F.2d 326, 332 (2d Cir. 1973) (depositors have no cause of action for bank's voluntary surrender of signature cards to F.B.I. agents).

40. FED. R. Crv. P. 24(a)(2) specifically allows intervention as of right by an individual who has "an interest relating to the property ... which is the subject of the action" and who "is so situated that the disposition of the action may as a practical matter impair or impede his ability to protect that interest." 
that "there is no ... constitutional issue in the case" 41 and nowhere mentioned the Fourth Amendment in determining whether the taxpayer had a "significantly protectable interest." 42 Since only "routine business records" were involved, the Court may have justifiably assumed $a b$ initio that the taxpayer could raise no Fourth Amendment claims. Arguably, with this assumption in mind the Court then found it necessary to hold that the taxpayer also lacked any proprietary interest, since proprietary interests would have given him separate grounds for intervention under Rule 24 even in the absence of Fourth Amendment interests. ${ }^{43}$ Putting this argument aside, Donaldson does not hold that a proprietary interest is necessary to protect the seizure or summons of all types of third party records. The Court noted that the records sought by the government were not "in the hands of [the taxpayer's] attorney or his accountant, with the attendant question of privilege, or even in the hands of anyone with whom the taxpayer has a confidential relationship of any kind." ${ }^{44}$ Confidential relationships are thus an additional source of individual rights; and the Court arguably implies that confidentiality may give rise to "significantly protectable interests" even in circumstances where no evidentiary privilege exists. Donaldson may thus leave open the possibility that proprietary interests will not be the sole determinant of Fourth Amendment rights when a confidential relationship is before the Court. ${ }^{45}$ Moreover, in holding that taxpayers may permissively inter-

41. 400 U.S. at 522. The Court, in stating that there was no "constitutional issue," was merely reiterating the settled doctrine that the issuance and enforcement of IRS summonses are constitutionally permissible means of obtaining the production of documents, i.e., that apart from the facts of any particular case, the practice of issuing summonses does not violate the Fourth Amendment. See United States v. Shlom, 420 F.2d 263, 266 (2d Cir. 1969), cert. denied, 397 U.S. 1074 (1970) (IRS summons that is reasonable in scope and issued for proper purpose does not "constitute an unlawful search and seizure in violation of the Fourth Amendment"); United States v. First Nat'l Bank of Mobile, 295 F. 142, 143-44 (S.D. Ala. 1924), aff'd per curiam, 267 U.S. 576 (1925) (where information sought was relevant and material to investigation of taxpayer, IRS could constitutionally require bank to produce documents through issuance of summons; individual taxpayers' claims were not before the court); United States v. First Nat'l Bank of Pikeville, 274 F. Supp. 283, 284-85 (E.D. Ky. 1967), aff'd per curiam sub nom. Justice v. United States, 390 U.S. 199 (1968) (section 7604 of INT. REv. CODE of 1954 authorizing judicial enforcement of IRS summons is constitutional and not violative of the Fourth Amendment).

42. 400 U.S. at 530-31.

43. Normally, of course, proprietary interests give rise to coexisting Fourth Amendment interests. See p. 1445 supra. However, where a third party in custody and control of records has authority to consent to a search and does so, the individual's Fourth Amendment interest is relinquished (for purposes of that search) although proprietary interests remain. In Donaldson the corporate record holder was willing to consent to a government search. See 400 U.S. at 521 .

44. 400 U.S. at 523 .

45. But cf. United States v. Bremicker, 365 F. Supp. 701, 702-03 (D. Minn. 1973). There a bank asserted that its confidential relationship with depositors prevented it from being compelled to produce information concerning its depositors. The court re- 
vene in certain enumerated circumstances, Donaldson shows some sensitivity to what are effectively Fourth Amendment claims. ${ }^{46}$

\section{B. Checks as Property and Mandatory Recordkeeping}

Even within a narrow property orientation, however, depositors may have a Fourth Amendment interest in certain checking account records. At common law, cancelled checks (and arguably items such as deposit slips and debit memos) are the depositor's property. ${ }^{47}$ Since ownership of records alone is probably sufficient to create a Fourth Amendment interest, an individual should be able to challenge an unreasonable search and seizure of his cancelled checks even while these items are in the bank's custody. If possession of documents were also deemed necessary, Fourth Amendment interest might still exist,

jected the bank's claim: Confidentiality notwithstanding, the bank's relationship with depositors has no evidentiary privilege. The court also denied without discussion the depositor's attempt to intervene.

46. Donaldson implied that taxpayer intervention may be allowed where a summons is issued in bad faith, solely to obtain evidence in a criminal prosecution, or where enforcement would abuse the court's process (e.g., where the summons was for documents not relevant and material to the investigation). 400 U.S. at 530-31, 536. These claims are substantively identical to those which the taxpayer could assert under the Fourth Amendment. See note 162 infra. The difference is mainly procedural: With a Fourth Amendment interest the taxpayer is automatically a necessary party to a proceeding to summon his bank records and is thereby entitled to notice.

47. Title to these items is of virtually no commercial importance and has not been disputed in litigation in over fifty years. At common law a check became the property of the drawer when paid; thereafter the bank held the check only as the drawer's agent. See Van Dyke v. Ogden Sav. Bank, 48 Utah 606, 615.16, 161 P. 50, 54 (1916); The Queen v. Watts, 169 Eng. Rep. 398, 401 (C.A. 1850); Burton v. Payne, 172 Eng. Rep. 236 (K.B. 1827); Partridge v. Coates, 171 Eng. Rep. 976, 977 (K.B. 1824); J. Grant, A Treatise on THE Law Relating to Bankers and Banking $75-78$ (1857) $2 \mathrm{~J}$. Morse, A Treatise on the Law of Banks and Banking $\$ 460$ (6th ed. 1928). See also UNIFORM COMMERCIAL CODE $\$ \S 4-201$, 4-105(d), 4-208. The bank may retain possession of the checks for bookkeeping purposes until the drawer's account is settled (e.g., in the event of an overdraft). See $2 \mathrm{~J}$. MORSE, supra, $\$ 460$. A few banks are now contemplating the retention of cancelled checks to reduce processing and mailing costs. Telephone interview with Matthew Hale, General Counsel to Am. Bankers Ass'n, Washington, D.C., Mar. 29, 1974. Retention would not divest the drawer of title; at most it would be a contractual alteration of rights, which need not be recognized for Fourth Amendment purposes. See Swarb v. Lennox, 405 U.S. 191-201 (1972); D.H. Overmeyer Co. v. Frick Co., 405 U.S. 174, 187-88 (1972) (contractual waiver of due process rights to notice and hearing prior to a civil judgment by means of a cognovit clause is not an issue of mere contract law; legal consequences of waiver are dependent upon factors such as voluntariness, knowledge of consequences, disparity of bargaining power, whether the contract is one of adhesion, and the individual's receipt of benefits for his waiver of rights). The contractual alteration, if it derogated the depositor's Fourth Amendment rights, might also be considered ineffectual for lack of "good faith" or "ordinary care" under the UNIFORM COMMERCIAL CODE $\$ 4$-103(1), or would perhaps be considered unconscionable under $\S 2.302$ of the UCC. See 22 U. Fla. L. REv. 482, 486 (1970).

Title to deposit slips has apparently never been litigated. The rationale supporting the depositor's ownership of paid checks, however, could be applied to support the customer's title in deposit slips. Deposit slips like paid checks are customarily returned, and their evidentiary value is of primary use to the depositor. $2 \mathrm{~J}$. MORSE, supra, $\$ 460$. 
based on "constructive possession." In Schwimmer $v$. United States 48 the Eighth Circuit held that a taxpayer's constructive, rather than actual, possession of documents enabled him to assert his Fourth Amendment claims against a government subpoena of the documents. Schwimmer, a retired attorney, had placed his records in the custody of a storage company for safekeeping. The court declared that the government could not avoid "the question of an unreasonable search and seizure ... through the mere procedural device of compelling a third party naked possessor to produce and deliver [the documents]."49 The same argument applies to the depositor's cancelled checks and deposit slips in bank custody. Banks are only slightly more than "naked possessors" of cancelled checks. Except for the use of paid checks in reconciling its statement with the depositor, a bank holds these items as the depositor's agent; indeed, the depositor is said at common law to have "constructive possession" of cancelled checks. ${ }^{50}$ But regardless of whether the ability to assert Fourth Amendment rights is based on ownership alone or on constructive possession, the resulting Fourth Amendment protection is scant. A proprietary interest test limits the depositor's Fourth Amendment interest to documents which he owns-original cancelled checks and deposit slips. Banks usually retain these items for less than a month. Most government searches are of microfilms and photocopies, items which, unlike the originals, are the bank's property and, therefore, not subject to the individual's Fourth Amendment claims.

Ironically this limited coverage may be expanded by the Bank Secrecy Act, whose implementation has often been criticized as a threat to civil liberties. ${ }^{51}$ Mandatory bank photocopying under the Secrecy Act ${ }^{62}$ is functionally equivalent to a physical seizure. If checks

48. 232 F.2d 855 (8th Cir. 1956); cf. Brown v. United States, 411 U.S. 223, 230 n.4 (1973).

49. 232 F.2d at 861 .

50. See Burton v. Payne, 172 Eng. Rep. 236 (K.B. 1827); Partridge v. Coates, 171 Eng. Rep. 976 (K.B. 1824). Furthermore, the argument underlying the Schwimmer decision is partially equitable in nature. Since Schwimmer could be personally compelled by subpoena to produce the records (although not in his actual possession), he should be allowed to contest their production by the third party. The same equities are present in the case of bank retained cancelled checks.

5l. See, e.g., California Bankers Ass'n v. Shultz, 94 S. Ct. 1494, 1526 (1974) (Douglas, J., dissenting); id. at 1533 (Marshall, J., dissenting); Bank Disclosure Hearings, supra note 3, at 21-24; Golembe \& Melvin, Keeping It Confidential-The Bank Secrecy Act, Bank Marketing Management, Sept. 1972, at 15-16; 37 Alb. L. Rev. 566, 579 (1973).

52. Banks must maintain copies of signature cards, ledger cards, and the depositor's social security or taxpayer identification number. 31 C.F.R. $\$ 103.34$ (1973). Copies of checks upon which the bank is drawee must be maintained unless 1) the item is for less than $\$ 100$, or 2) the check is for payrolls, employee benefits, government agencies, or other exceptions specifically listed in $\$ 103.34(\mathrm{~b})(3)$. Until the amendment of January 17, 1973, 38 Fed. Reg. 2175, 2176 (1973), there was no exemption for checks under $\$ 100$; for a discussion of this exemption, see Bank Disclosure Hearings, supra note 3 , at 78 . Banks which at present photocopy or record checks deposited 
were removed from bank premises by government agents, photocopied while in government possession, and then returned, the checks would surely be considered "seized." Forcing bank employees, rather than government agents on the federal payroll, to conduct the information gathering on bank premises should not make the photocopying any less a state-instigated search or seizure whose fruits are photocopies and microfilms. ${ }^{\tilde{3} 3}$ Any attempt to use the copies as fruits of the search may be forbidden by the Fourth Amendment protection given the original checks. ${ }^{54}$

In the context of bank recordkeeping there is a separation of time between the events of physical seizure and actual government access. This creates a novel set of problems regarding the conception of a search, its reasonableness, and the imposition of Fourth Amendment sanctions. Normally the reasonableness of a search and seizure is measured in "proportion to the end sought." 55 But where physical taking and government acquisition of data are separate events, the "ends" of

to its customer's account in the ordinary course of business must retain such records for two years pursuant to 31 C.F.R. $\$ \$ 103.34(\mathrm{~b})(10), 301.36$ (c) (1973). Other records required by $\S 103.34$ must be retained for five years. 31 C.F.R. $\$ 103.36$ (c) (1973).

Under 31 C.F.R. $\$ 103.22$ (a) (1973), the bank must report, on forms provided by the Treasury Department, any currency transaction which exceeds $\$ 10,000$. unless the exceptions of 31 C.F.R. $\$ 103.22$ (b) (1973) apply. Under 31 C.F.R. $\$ \$ 103.23$ and 103.25 individuals who transport monetary instruments exceeding $\$ 5,000$ into or out of the United States must report such transactions to the government.

53. See California Bankers Ass'n v. Shultz, 94 S. Ct. 1494, 1514 (1974) ("the bank in making the records required by the Secretary [of the Treasury] acts under the compulsion of the [Treasury] regulation").

Evidence obtained by private party searches is not subject to the Fourth Amendment's proscriptions. Burdeau v. MícDowell, 256 U.S. 465 (1921); 44 N.Y.U. L. REv. 206 (1968). However, when the search is planned, instigated by, or is conducted on behalf of federal authority, Fourth Amendment sanctions apply even though private parties carry out the search and seizure. See Lustig v. United States, 338 U.S. 74, 78.79 (1949); Gambino v. United States, 275 U.S. 310, 315-18 (1927); Corngold v. United States, 367 F.2d 1, 5-6 (9th Cir. 1966); People v. Baker, 12 Cal. App. 3d 826, 837, 90 Cal. Rptr. 508, 515 (1971).

National banks, since M'Culloch v. Maryland, 17 U.S. (4 Wheat.) 316 (1819), have been considered federal instrumentalities. See generally Schwind \& O'Leary, Are Na. tional Banks Federal Instrumentalities Today?, 86 BANking L.J. 99 (1969). Thus, they could technically be considered government agents even without the compulsion of the Bank Secrecy Act.

54. Accord, Silverthorne Lumber Co. v. United States, 251 U.S. 385 (1920). Government agents in that case illegally seized and photocopied corporate records. The corporation successfully moved for a return of the original records. However, the government then attempted to use the photocopies as the basis for a subpoena to compel production of the original records. The court barred evidentiary use of the photocopies, since they were fruits of an unreasonable search and seizure.

The fact that bank photocopies are "required records" does not, of course, eliminate the depositor's Fourth Amendment interest. See, e.g., Davis v. United States, 328 U.S. 582 (1946) (defendant allowed to assert Fourth Amendment claim even though items seized were gas rationing coupons that were "public documents" which defendant was required to keep at his place of business); cf. Cravens v. United States, 62 F.2d 261 (8th Cir. 1933) (bank examiners could reveal to the Justice Department evidence concerning illegal activity of bank officers obtained in general atdit of bank, but officers could assert claims of illegal search in respect to their own private papers).

55. McMann v. SEC, 87 F.2d 377, 379 (2d Cir.), cert. denied, 301 U.S. 684 (1937). 
the seizure cannot be determined without reference to the unknown purposes of future government inquiries. ${ }^{56}$ One approach is to view government acquisition of bank data as completing the "seizure." Fourth Amendment sanctions apply only when government access is attempted. Reasonableness is then judged according to the purposes of the actual government access. ${ }^{57}$

A technically difficult problem to resolve is the identification of the records deemed to be "fruits" of a government-instigated seizure. Under a proprietary view of the Fourth Amendment an individual's protected interest is limited to copies of depositor-owned documents made or maintained pursuant to a federal statute. Prior to the Secrecy Act a number of banks were already copying all of their depositors' cancelled checks. ${ }^{58}$ Since their actions are undertaken independently

56. If a court presumes that the government will engage in only illegal surveillance, photocopying of records needed for sound bank regulation may unwisely be prohibited. The Court in California Bankers Ass'n v. Shultz, 94 S. Ct. 1494 (1974) avoids this error in sustaining the recordkeeping provisions of the Bank Secrecy Act and Treasury regulations. Left unguarded is the complementary pitfall: By presupposing only legitimate government access to bank records, the Court would extinguish individuals' Fourth Amendment claims. Once record maintenance standing alone is deemed a completed, reasonable seizure, bank microfilms would no longer be tainted fruits as to which depositors could invoke Fourth Amendment protection. Valid regulatory purposes would thus be used to shelter later, unreasonable government searches of the microfilms (in which the depositor has no proprietary interest).

57. Assuming arguendo that the Court in California Bankers Ass'n vo Shultz, 94 S. Ct. 1494 (1974), was operating within a proprietary interest orientation, the Court left unclear its view of this theoretical problem. Justice Rhenquist's blunt statement is of little help: "That the bank in making the records . . . acts under the compulsion of the [Treasury] regulation is clear, but it is equally clear that in doing so it neither searches nor seizes records in which the depositor has a Fourth Amendment right." Id. at 1514. Since a physical seizure undeniably occurs when documents are obtained to be photocopied, what Justice Rhenquist must be saying is that, for Fourth Amendment purposes, no "seizure" takes place which invades depositors' rights. Three interpretations of this statement then present themselves. First, depositors have no Fourth Amendment interest in original cancelled checks, let alone bank microfilms, which would allow them to protest a seizure. Second, even if Fourth Amendment interests exist, mandatory recordkeeping is a reasonable seizure, complete unto itself. Third, depositors' Fourth Amendment claims, if they exist, are premature and will be considered only when the government attempts to obtain access to the records.

The first explanation seems unlikely. At no point does the opinion discuss the proprietary status of cancelled checks or Fourth Amendment doctrine as to protection of objects owned but not possessed. Choosing between the second and third interpretation is extremely important in determining the depositor's subsequent rights, but the Court gives little guidance. The Court's statement that subsequent government access to the records would "be controlled by existing legal process," id. at 1513, does not necessarily imply the ability to assert Fourth Amendment interests, particularly since this phrase immediately precedes the majority's discussion of an individual's lack of rights to contest third party summons.

58. Prior to the Bank Secrecy Act most banks maintained copies of checks drawn on out-of-town banks and sent for collection. See, e.g., United States v. First Nat'l Bank of Mobile, 67 F. Supp. 616, 619 (S.D. Ala. 1946). Many small and intermediate size banks and some large banks also photocopied all or most of their depositors" cancelled checks. However, the extent and period of recordkeeping did not necessarily correspond to the Treasury regulations discussed in note 52 supra. For example, the First New Haven National Bank usually retained copies of out-of-town checks deposited with it for little more than one year. Interview with Donald Redfield, Comptroller of First New Haven Nat'l Bank, in New Haven, Conn., Oct. 9, 1973. Regu- 
of the Act's requirements, it may not be proper to characterize their records as products of a government-instigated "seizure." However, a factual determination of which records were copied solely in compliance with the Act would result in differences in Fourth Amendment protection from bank to bank. Alternatively, to declare all record-maintenance under the Act to be state action would produce a vast expansion of Fourth Amendment interests-a curious twist of fate since the Secrecy Act was passed as a measure to impose stricter controls on white collar crime.59 A middle ground might be sought by adopting a set of conclusive evidentiary presumptions concerning "state action" and photocopying. ${ }^{60}$ Even in this task the structure of the Treasury regulations requiring recordkeeping creates identification problems. Amended regulations require banks to copy only items in excess of $\$ 100 .{ }^{61}$ Yet the cost of sorting is so expensive that many banks find it cheaper to duplicate all items. ${ }^{62}$ Arguably, photocopying resulting directly from the regulations' economic impact should also be considered state-instigated, but that result is by no means logically compelled.

These difficulties make it clear that any protection dependent upon the proprietary status of bank records is tenuous at best. The argument is suspended by a thread of legal history. The 19th century cases $^{63}$ which recognize the depositor's property interest in paid checks have remained unquestioned precisely because there has been no genuine need-commercial or otherwise-to relitigate the issue. Further-

lations under the Act now require retention for two years. 31 C.F.R. $\$ \$$ 103.36(c), 103.34(b)(3), 103.34(b)(6), 103.34(b)(10) (1973). Some large banks did not maintain photocopies of their depositors' checks, because it was cheaper to self-insure against loss of items than to establish extensive recordkeeping machinery. See H.R. REP. No. 975, 9lst Cong., 2d Sess. 11 (1970). The five largest banks in California fell into this latter category and maintained very few photocopies. Telephone Interview with Andrew J. Shephard, Pres. of the Exchange Bank of Santa Rosa, Immediate Past Pres. of the Cal. Bankers Ass'n, in Santa Rosa, Cal., Oct. 19, 1973.

Variance in bank recordkeeping practices is also noted in Secrecy Act Hearings, supra note 5 , at 72-74, 320-21, 325-27, 340. See also Bank Disclosure, Hearings, supra note 3 , at 86.

59. See California Bankers Ass'n v. Shultz, 94 S. Ct. 1494, $1500-02$ (1974); H.R. REP. No. 975, 91st Cong., 2d Sess. 10, 16 (1970); Jurisdictional Statement of George $P$. Shultz at 16-17, California Bankers Ass'n v. Shultz, supra: Golembe \& Milvin, supra note 51 , at 15,16 .

60. A court could presume, for example, that banks in their ordinary course of business copied only items in excess of $\$ 10,000$ and only checks deposited which were drawn on out-of-town banks. Thus, state action would be deemed to exist with respect to all photocopies made under the Secrecy Act, except for a small number of items copied under 31 C.F.R. $\$ 103.34(b)(1)(1973)$, and items copied under 31 C.F.R. $\S \S 103.34(\mathrm{~b})(4)-(9)(1973)$.

61. See 31 C.F.R. \$ 103.34 (1973).

62. See BANK.Systems \& EQuIP., Mar. 1973, at 18; Telephone Interview with Matthew Hale, supra note 47 .

63. See cases cited in note 47 supra. 
more, a court interested in the minutiae of check processing can occasionally find the property connection (and thereby the depositor's Fourth Amendment interest) severed by trivial variances in banking practice. For example, if a bank microfilms checks before the drawer's account is debited, the drawer has no proprietary interest (i.e., no title to the instrument) at the time the seizure occurs and therefore has no Fourth Amendment claim. ${ }^{04}$ The entire argument thus remains inherently fragile due to adherence to technicalities of property law and banking practice. Such technicalities produce distinctions bearing no rational relationship to any underlying concern for privacy. ${ }^{65}$

\section{Information as Property}

The property approach to the Fourth Amendment is not without expansive potential, however, as demonstrated in Brex $v . S m i t h^{66}$ and Zimmerman $v$. Wilson, ${ }^{67}$ which are curious aberrations from the traditional treatment afforded bank records. The cases involve attempts of government agents to subpoena depositors' bank records in order to obtain evidence for civil purposes and to investigate possible criminal activity. In construing the nature of Fourth Amendment interests, Brex and Zimmerman rely upon property doctrine but safeguard bank depositors' privacy by conceptualizing information as property:

It is the information the bankers' books contain, and not the books in which that information is recorded, that is the property right of these taxpayers, a property right this court protects by injunctive relief. ${ }^{68}$

The scope of Fourth Amendment protection is increased by enlarging the concept of property. Information becomes the object seized, and, as an object owned by the depositor, subject to Fourth Amendment

64. An electronic funds transfer system, discussed in notes $12-13$ supra, would climinate all vestiges of property owned by the depositor-and thereby any Fourth Amendment interests-despite the fact that no basic change in character of the relationship between depositor and bank has occurred.

65. The district court in Stark v. Connally, 347 F. Supp. 1242, 1248 (N.D. Cal. 1972), aff'd in part, rew'd in part sub nom. California Bankers Ass'n v. Shultz, $94 \mathrm{~S}$. Ct. 1494 (1974), avoided "the technical question whether customer's checks, as such, become the property of the bank during the banking process" in analyzing Fourth Amendment protection of bank records. The Supreme Court did not address the issue.

66. 104 N.J. Eq. 386, 146 A. 34 (Ch. 1929).

67. 81 F.2d 847 (3d Cir. 1936). The novel holding of this case was reversed at least as to the brokerage records involved, however, in Zimmerman v. Wilson, 105 F.2d 583 (3d Cir. 1939).

68. 81 F.2d at 849 . 
protection. ${ }^{60}$ The Brex and Zimmerman opinions, however, also suggest other grounds for their holdings ${ }^{70}$ and thus become imprecise minglings of property, privacy, and Fourth Amendment doctrines. Moreover, the approach requires a marked extension of the common law, which has traditionally recognized information as property only in the form of commercially valuable information. ${ }^{71}$ Without the "commercially profitable" criteria, it is difficult to determine in what information and under what conditions the property right arises. ${ }^{72}$ Nonetheless, from the perspective of the Fourth Amendment, the theory of information as property is an open road to innovation..$^{73}$

\section{Informational Control and Expectations of Privacy}

Although historically linked with property, the Fourth Amendment was designed as a protection of the individual's privacy from governmental abuse, specifically from the government's use of writs of as-

69. The results of both cases suggest that ownership of such property, even absent possession, is sufficient to grant standing. Neither case treats as separate issues the seizure of records and the search of the banks; cf. United States v. Jeffers, 342 U.S. 48 (1951) (discussed in note 28 supra). Zimmerman may also adopt a theory of constructive possession by regarding "bankers and brokers as mere agents." 81 F.2d at 849.

70. A right to privacy is mentioned in 81 F.2d at 849 , and in 104 N.J. Eq. at $390-91,146 \mathrm{~A}$. at 36 . The Brex opinion also has overtones of both abuse of process and equitable action to prevent irreparable destruction of property rights. 104 N.J. Eq. at $387-90,146 \mathrm{~A}$. at $35-36$.

71. See generally International News Serv, v. Associated Press, 248 U.S. 215 (1918); Chicago Bd. of Trade v. Christie Grain \& Stock Co., 198 U.S. 236, 251 (1905); Pearson v. Dodd, 410 F.2d 701 (D.C. Cir.), cert. denied, 395 U.S. 947 (I969); McMann v. SEC, 87 F.2d 377 (2d Cir.), cert. denied, 301 U.S. 684 (1937); Pittsburgh Athletic Co. v. KQV Broadcasting Co., 24 F. Supp. 490 (W.D. Pa. 1938); Dodge Co. v. Construction Information Co., 183 Mass. 62, 66 N.E. 204 (1903); A. Westin, Privacy and Freedom 324-25 (1970); Philbrick, Changing Conceptions of Property in Law, 86 U. PA. L. REv. 691, 693, 701 (1938); Warren \& Brandeis, The Right to Privacy, 4 Harv. L. REv. 193, 200.01 (1890).

72. As noted by A. Miller, The Assault on Privacy 213 (1971), "resort to property is objectionable in that it involves the manipulation of a conclusory label." See generally id. at 210-16.

73. State courts, which normally adjudicate the existence of property relationships, may heed the directions by Katz v. United States:

[T] he protection of a person's general right to privacy-his right to be let alone by

other people-is, like the protection of his property and of his very life, left largely

to the law of the individual States.

389 U.S. $347,350-51$ (1967).

Moreover, recognition of proprietary rights to create a "wealth of privacy" is con: sistent with Professor Reich's thesis that property has historically served "to guard the troubled boundary between individual man and the state." Reich, The New Property, 73 YALE L.J. 733 (1964). "Property draws a circle around the activities of each private individual. :. Within that circle ... he is master, and the state must explain and justify any interference. . . The Bill of Rights also serves this function - [but] in the final analysis the Bill of Rights depends upon the existence of private property." Id. at 771. See generally id. at 769-74. 
sistance and general search warrants. ${ }^{74}$ Physical embarrassment and harassment were among the evils feared. ${ }^{75}$ But also prominent in the Amendment's creation was the threat of government authorities searching through private books and papers to glean evidence of wrongdoing. In particular the framers sought to incorporate the decision of Entick v. Carrington ${ }^{76}$ into the Constitution. ${ }^{77}$ That case involved a civil suit against agents of the Crown for their seizure of the books and papers of John Entick, an author who, Lord Halifax believed, had published several seditious pamphlets. In outlawing the use of general warrants Entick v. Carrington was concerned with more than physical intrusion: another aspect of privacy-the individual's loss of control of information-was at stake. Lord Camden's famous opinion expressed abhorrence that the individual's "house is rifled, his most valuable secrets are taken out of his possession ...." 78 A fear that "the secret cabinets and bureaus of every subject in this kingdom will be thrown open to the search and inspection of a messenger"70 prompted the court's holding.

The Fourth Amendment's drafters were thus concerned with privacy in the sense of control over information. ${ }^{80}$ However, written against the background of a 1791 society in which property relationships were sufficient to protect the individual's privacy, ${ }^{81}$ the Fourth

74. Stanford v. Texas, 379 U.S. 476, 482 (1965). For descriptions of the history of the Fourth Amendment, see Warden v. Hayden, 387 U.S. 294, 301-11 (1967); Stanford v. Texas, supra, at 481-85; Marcus v. Search Warrant, 367 U.S. 71\%, 724-29 (1961); Frank v. Maryland, 359 U.S. 360, 363-65 (1959); J. LANDYNSKI, SEARCH AND SEIzURE ANd THE Supreme Court (1966); N. LAsson, The History and Developaent of the Fourth Amendment to the United States Constitution (1937).

75. Colonists reportedly "complained that "our houses and even our bed chambers are exposed to be ransacked, our boxes, chests, and trunks broke open, ravaged and plundered by wretches, whom no prudent man would venture to employ even as menial servants." R. Rutlaid, ThE BIRTH of THE BILL of Rights 25 (1955), quoted in Warden v. Hayden, 387 U.S. 294, 315 (1967) (Douglas, J., dissenting).

76. 19 How. St. Tr. 1029 (C.P. 1765).

77. In Stanford v. Texas the Court described Entick v. Carrington as "a wellspring of rights now protected by the Fourth Amendment." 379 U.S. at 484 . Boyd v. United States, 116 U.S. 616, 626-27 (1886), asserts a similar proposition, noting that the Entick case was "in the minds of those who framed the Fourth Amendment."

78. 19 How. St. Tr. at 1064 .

79. Id. at 1063 .

80. Professor Alan Westin defines privacy as

the claim of individuals, groups, or institutions to determine for themselves when,

how, and to what extent information about them is communicated to others.

A. WESTIN, PRIVACY AND FreEdom 7 (1970).

81. D. Flaherty, Privacy in Colonial New England 25.44 (1972), discusses in detail the contributions to colonial privacy made by the sparsity of population, the linear design of towns, the large acreage lots, and the architecture of homes-all factors that reflect real property distribution and relationships. Indeed, "[ $t$ ] he only kinds of searches and seizures that [the Framers] knew about involved physical intrusions and the seizure of persons and tangible things." Hufstedler, The Directions and Mis-Directions of a Constitutional Right of Privacy, 26 RECORD OF N.Y.C.B.A. 546, 552 (1971). 
Amendment refers to only one mode of informational control-ownership of property. ${ }^{82}$

Dramatic increases in urbanization ${ }^{83}$ and technology have caused property and privacy interests to diverge. Economic specialization has largely supplanted the individual's house or papers as repositories for personal information; computers are more efficient. There is today dependence upon hospitals and doctors' offices rather than upon bedside physicians, ${ }^{84}$ telephonic communications rather than direct conversation, ${ }^{85}$ and bank-intermediated transactions in place of direct payments, ${ }^{86}$ all of which generate second or third party records. Rather

82. Liberty and property were closely linked in the Framers minds and speech. Philbrick, supra note 71 , at 713 . Professor Charles Reich also states, "[T] ide idea of privacy being invaded in the way it can be today never occurred to the people who wrote the Bill of Rights ... [but] every way in which they understood privacy ... [was] protected ... in the Constitution." Hearings Before a Subcomm. of the House Comm. on Gov't Operations, 89th Cong., 2d Sess. 29 (1966).

The Drafters' choice of property terms might have been dictated by another factor: Authority to seize goods was based upon the sovereign's assertion of a superior property interest in the goods themselves. Warden v. Hayden, 387 U.S. 294, 303-06 (1967); Kaplan, Search and Seizure: A No-Man's Land in the Criminal Law, 49 CaLIF. L. REv. $474,475(1961)$.

83. In 1790 less than six percent of the United States population was in urban areas. The percentage had grown to 35 percent by 1890 and to 73 percent by 1970 . U.S. Bureau of THE Census, Statistical Austract of the United States: 1972, at 5, 17,24 (1972).

84. Besides a mental institution in Williamsburg, Virginia, the only hospital functioning in the United States prior to 1791 was in Philadelphia. The number of patients treated by the Philadelphia hospital was small-only 89 per year in $1754-55$. See F. Packard, The History of Medicine in the United States 174, 340, 364 (1901); M. Risley, The House of Healing 215-32 (1961). By contrast there were over 7,000 hospitals and mental institutions in the United States in 1970. U.S. BUREAU OF THE Census, supra note 83 , at 71 .

85. Sources gathered by D. FlaherTY, supra note 81 , at $117 \mathrm{n} .10$, indicate that letter writing prior to 1800 was uncommon-less than one and a half letters per person per year-and was mostly confined to merchants and the wealthy. Without telephones or a widely used postal service, communication was necessarily direct between individuals. In 1971 , by contrast, the Post Office was handling 51 billion pieces of first class mail each year-over 250 letters per capita. U.S. BUREAU OF THE CENSUS, supra note 83 , at 491 . The telephone company appears as an equally formidable intermediary. Ninety percent of all households have telephones, totaling over 91 million residential telephones. An enormous quantity of records is generated: on average more than 500 million calls are made daily, of which 29 million are long distance. Id. at 493 .

86. The colonial "bank" existed principally to issue paper notes; not until the chartering of the Bank of North America in 1781 did the first commercial bank-in today's terminology-opęrate in America. See W. Spahr, The Clearing and Collection of Checks 42-43 (1926); W. WARner, BANking 48-60 (1895). The absence of deposit banking almost completely inhibited the development of checks; specie and paper currency were overwhelmingly the medium of exchange during the colonial era. See W. Spahr, supra, at 37-43; $\dot{A}$. Davis, The Fund at Boston in NEw England 13-18 (1903). See also W. Gouge, Paper Money And Banking, pt. II, 53-54 (1833). In 1791, when the Fourth Amendment was adopted, there were at most six banks in the United States and therefore necessarily few checking accounts. See W. Gouge, supra, at 42; W. SPAHR, supra, at 49 .

Widespread consumer use of checking accounts-described as a "shift from class to mass banking"-is only a recent phenomenon that accompanied the expansion of credit after World War II. See R. Aldom, A. Purdy, R. SchNeider \& H. WitminghaM, Au- 
than suppress personal information or confine it to his home, which would be-if not impossible-grossly inefficient and severely restrictive of social and financial intercourse, the individual chooses third party intermediaries whom he believes will protect his privacy. Custom, statutory restrictions, and private remedies serve to enforce these expectations of privacy. ${ }^{87}$ Yet, under a "proprietary interest" interpretation of the Fourth Amendment, these nonproperty modes of informational control go unrecognized: Privacy is protected only if embodied in a proprietary relationship.

Fourth Amendment law has exhibited a slow but marked recognition of the divergence of property and privacy. The Supreme Court, in particular, has given increasing weight to concepts of privacy; Fourth Amendment protection has been both curtailed within and expanded beyond the limits of property law. "House" now includes an "apartment" 88 or "business office," 89 both places where one may have an expectation of privacy. By contrast, individuals cannot assert a Fourth Amendment interest in open fields ${ }^{90}$ or in premises they have leased to others, ${ }^{01}$ despite the existence of ownership and the violation of a property right enforceable at common law through a trespass action. Proprietary interest, as a requisite to contest the search of premises, is now satisfied by lawful occupancy of the place searched. ${ }^{92}$ But until 1967, property relationships-even if only occupancy-still delineated the scope of Fourth Amendment rights.

In 1967, Katz $v$. United States ${ }^{93}$ significantly revised the conceptual method of determining the existence of Fourth Amendment interests. In holding that electronic surveillance of a telephone booth was in violation of the Fourth Amendment, the Court did not focus upon possessory or occupant interests (i.e., proprietary interests) in the tele-

tomation in Banking 13-15 (1963); B. Yavitz, Automation in Commercial Banking 7-17 (1967). Projections indicate that by 1975 some 29 billion checks will be processed annually drawn on 92 million checking accounts. 85 MoNTHLY LABOR REv. 992 (1962).

87. See, e.g., 47 U.S.C. $\$ 605$ (1970); 18 U.S.C. $\$ 2511$ (1970) (telephone company or its employees prohibited from divulging the "existence, contents, substance, purport, effect, or meaning" of communications); OHIO REv. CODE ANN. \$ 2317.02 (Page 1953) (physician-patient evidentiary privilege); Hammonds v. Aetna Cas. \& Sur. Co., 243 F. Supp. 793 (N.D. Ohio 1965) (physicians may be liable for unauthorized disclosure of information concerning patients). See also 15 U.S.C. \$\$ 1681-1681t (1970) (credit reporting agencies subject to statutory limitations and penalties for release of information gathered on consumers).

88. Jones v. United States, 362 U.S. 257 (1960).

89. Mancusi v. DeForte, 392 U.S. 364 (1968).

90. Hester v. United States, 265 U.S. 57 (1924). At common law, governmental entry into even an open field required a warrant. Kaplan, supra note 82 , at 481 .

91. See United States v. Reckis, 119 F. Supp. 687 (D. Mass. 1954).

92. See Mancusi v. DeForte, 392 U.S. 364 (1968).

93. 389 U.S. 347 (1967). 
phone booth or the surrounding space. ${ }^{94}$ Instead, the defendant's Fourth Amendment interest depended upon the existence of "privacy upon which he justifiably relies." ${ }^{5}$ The Court's holding and the concept of "constitutionally justified expectations of privacy"96 are conceptually independent of property doctrine. Primary emphasis shifts from ownership, possession, and occupancy to expectations.

Despite this conceptual change, recent cases have not yet fully explored the implications of Katz. Mancusi v. DeForte, ${ }^{97}$ decided two years after $\mathrm{Katz}$, did speak in terms of "reasonable expectations of privacy." But in holding that an employee could contest the illegal seizure of files in his employer's office building, the Supreme Court directed attention to the employee's possession of the space in his office and his occupancy at the time of the search. Thus the decision relies heavily on a pre-Katz concept, the "constitutionally protected area." 98

Proprietary interest tests, however, have been altered by "justified expectations of privacy." In People v. Krivda ${ }^{99}$ the California Supreme Court, which adopted the Katz standard for state court decisions, held illegal a warrantless search of a trash can left for collection by the side of the road. The court implied that the property relationships were not necessary to its conclusion that an expectation of privacy existed.100 The dissenting opinion gave weight to the proprietary status of the trash, but stated that such status was not controlling. ${ }^{101}$ The property relationship involved was important because it helped determine expectation of privacy: "That expectation [of privacy], however, is inextricably bound up in the physical location of the trash cans." 102 Both majority and dissent thus looked beyond proprietary interests to assess the claimant's Fourth Amendment interest.

94. The defendant Katz did not even occupy the space where the electronic listening device was located, since the device did not penetrate the walls of the booth. Id. at 352. See generally Kitch, Katz v. United States: The Limits of the Fourth Amendment, 1968 Sup. Cr. REv. 133, 136.39. "[T] [Te [Katz] opinion is intentionally ambiguous, pointing the way to a new scope for the Fourth Amendment while leaving the Court room to retreat." Id. at 138 .

95. 389 U.S. at 353.

96. United States v. White, 401 U.S. 745, 751 (1971).

97. 392 U.S. 364, 368-70 (1968).

98. See Lanza v. New York, 370 U.S. 139, 142-45 (1962).

99. 5 Cal. 3d 357, 486 P.2d 1262, 96 Cal. Rptr. 62 (1971), vacated and remanded per curiam, 409 U.S. 33 (1972), aff'd on rehearing, 8 Cal. 3d 623, 504 P.2d 457, 10J Cal. Rptr. 521, cert. denied, 412 U.S. 919 (1973).

100. 5 Cal. 3d at 364-67, 486 P.2d at 1267-69, 96 Cal. Rptr. at 66-69. In order to decide expectations of privacy as well as the trash's proprietary status, the court examined the effects of a municipal ordinance and of police rummaging through trash. The court also focused on the suspect's subjective expectations.

101. Compare id., with United States v. Dzialak, 441 F.2d 212 (2d Cir. 1971) (trash placed at the side of the road is abandoned property; no Fourth Amendment protection can apply to it).

102. 5 Cal. $3 d$ at 367, 486 P.2d at 1269, 96 Cal. Rptr. at 69. 
Katz has not eliminated property considerations-ownership, possession, occupancy-but has changed their role from legal touchstones for the Fourth Amendment to standards by which expectations of privacy are evaluated. Property criteria justifiably remain relevant; but requiring a nexus of privacy with property would implicitly deny the existence of a legally protectable interest for almost all third party records. Bank depositors could conceivably claim an expectation of privacy based on the fact that, through receipt of their cancelled checks, they have historically had exclusive possession of all transactional information not contained in the bank's ledgers. ${ }^{103}$ Such a Fourth Amendment interest would at least shield the names of payees or endorsers contained in bank microfilms. But this "nexus" approach is anomalous: Reembracing property tests, it converts expectations of privacy into expectations of ownership, possession, or occupancy.

Although it denied Fourth Amendment protection, United States v. White ${ }^{104}$ made the most progressive analysis of the nature of Fourth Amendment interests. The Court in White explicitly focused on control over information, or more precisely, the defendant's lack of control over secrets revealed to a companion. The defendant claimed that the government violated his Fourth Amendment rights by concealing an electronic transmitter on an informant. In holding that recordings of his conversations with the informant were admissible evidence, the Court stated that White could not justifiably expect "that a person with whom he is conversing will not then or later reveal the conversation to the police."105 White's lack of control over a companion's behavior was held to preclude his Fourth Amendment claim:

If the law gives no protection to the wrongdoer whose trusted accomplice is or becomes a police agent, neither should it protect him when the same agent has recorded or transmitted the conversations. ${ }^{106}$

103. The nexus is historical only. Banks have, since 1928, often retained photocopies or microfilm of cancelled checks to insure against lost items or spurious claims. See generally Wharton, You're in the Pictures, AM. Bus., July 1955, at 14. But traditionally banks maintained few records concerning their depositors' checking accounts, and the information contained in these documents was generally limited to dates and amounts of debits and credits. With only few exceptions, the information, including names of payees and endorsees, was not recorded. See Ledgers of the Hartford Bank, Aug. 1792 to 1794; 1. BARRET, MODERN BANKING METhods 146-65 (5th ed. 1907); III R. Westerfield, Banking Principles and Practice $596-99$ (1921). See generally A. Barrett, supra, at 211-21; A. Fiske, THE MODERN BANks 79 (1904) (after clearinghouses developed, some banks would record additional information in "transit" ledger on checks sent for collection); Interview with John C. Foley, retired Ass't Treasurer of the Chemical Bank, New York City, Feb. 21, 1974 (some small country banks recorded names of payees of its customers' checks).

104. 401 U.S. 745 (1971).

105. Id. at 749 .

106. Id. at 752. The dissents of Justices Harlan and Douglas also looked to the defendant's control over information, and argued that the majority focused on the 
Judicial articulation of "justified expectations of privacy" has just begun and the exact boundaries of the standard remain unclear. Courts following the Katz decision appear to rely upon two broad criteria to determine the existence of expectations of privacy and to christen such expectations as "constitutionally justified": the actual degree of the individual's control over information and the desirability of such privacy or informational control. ${ }^{107}$ The latter criterion is difficult to weigh. A court assessing the desirability of informational control determines if such privacy has a significant impact upon the values which the Fourth Amendment seeks to preserve, e.g., autonomy, security, individuality. ${ }^{108}$ Since one's view of the desirability of privacy in various contexts is itself based upon conventional norms and mores, ${ }^{109}$ judicial evaluations of this criterion will undoubtedly vary. Courts not surprisingly have focused on the more tangible criterion, the actual existence of information control. Several decisions have recognized that the individual's control over information is often supported by constraints other than property relationships, e.g., a customary, confidential relationship between the individual and the recordkeeper and the nature of that relationship, ${ }^{110}$ an evidentiary privilege, ${ }^{111}$ or statutes, ordinances, or common law concerning access to

wrong mode of informational control. White's ability to keep sounds from being transmitted outside an enclosed area (rather than his control over his companion's behavior) was perhaps the more significant issue. See id. at 760,762-64,787-90; cf. Katz v. United States, 389 U.S. 347,352 (1967).

107. The two criteria are interrelated. A high degree of actual informational control may indicate a societal belief that privacy is very desirable. And conversely, legal recognition of privacy may be desirable in the circumstances simply because actual informational control has caused many individuals to rely upon privacy.

Even though a high degree of informational control is present, however, the privacy involved may not be sufficiently desirable to give rise to a Fourth Amendment interest; cf. McMann v. SEC, 87 F.2d 377, 379 (2d Cir.), cert. denied, 301 U.S. 684 (1937) (Learned Hand, J., denying Fourth Amendment protection to records of stock transactions).

108. These values are occasionally mentioned in cases and have been frequently discussed in legal literature. See, e.g., Brinegar v. United States, 338 U.S. 160, 180-81 (1949) (Jackson, J., dissenting); A. WEsTiN, supra note 80, at 31-51; Fried, Privacy, 77 YALE L.J. 475 (1968); Jourard, Some Psychological Aspects of Privacy, 31 LAW \& ConteMP. Prob. 307 (1966).

109. See A. Westin, supra note 80, at 11-30; Shils, Privacy: Its Constitution and Vicissitudes, 31 LAw \& Contemp. Prob. 281, 288-96 (1966).

110. Cf. Couch v. United States, 409 U.S. 322, 335 (1973). Couch, a Fifth Amendment case, applied the concept of "reasonable expectations of privacy" as a means of determining Fifth Amendment protection. The taxpayer in Couch was held not to have a reasonable expectation of privacy since, in giving records to her accountant, she expected him to disclose much of the information to government authorities in income tax returns. United States v. White, 401 U.S. 745,752 (1971), utilizes similar criteria, in holding that an accomplice cannot be expected to keep information on criminal activities to himself.

111. Cf. Couch v. United States, 409 U.S. 322, 335 (1973); Donaldson v. United States, 400 U.S. 517, 523, 531 (1971) (taxpayer may intervene in administrative subpoena enforcement proceedings to assert attorney-client or any other evidentiary privilege). 
the information and its disclosure.112 Through application of these criteria a court-without exclusively relying upon property law-can protect the modes of informational control which give rise to Fourth Amendment interests. ${ }^{113}$

When nonproperty constraints are considered, the depositor's expectation of privacy as to his checking account records becomes "justifiable" and deserving of constitutional protection. Although ledger card data are used to balance the bank's books, the banker has virtually no occasion to gain access to or make use of the underlying transactional information. ${ }^{114}$ Commercial banks have rigorously maintained the confidentiality of checking account transactions. ${ }^{115}$ Generally information is released to private parties only upon consent of the depositor ${ }^{116}$ and is confined to credit information. ${ }^{117}$ Raw trans-

112. See People v. Krivda, 5 Cal. 3d 357, 366, 486 P.2d 1262, 1268, 96 Cal. Rptr. 62, 68 (1971).

113. These criteria are flexible enough to distinguish certain types of records within an otherwise protected mode of informational control. For example, even if other records of a depositor's account are protected, signature card records of a bank depositor's account may not be sufficiently "private" to generate a Fourth Amendment interest; $c f$. Fifth Ave. Peace Parade Comm. v. Gray, 480 F.2d 326, 328, 332 (2d Cir. 1973). But cf. id. at 335 (Oakes, J., dissenting).

114. With the exception of a cursory inspection of the original item to insure that the check is not postdated and that signatures and endorsements are genuine, bankers rarely have any legitimate business use for the underlying transactional data. Once a check is paid and returned, these data-names of payees, dates on checks, endorsements, and other memoranda-are recorded only in microfilms of checks. A considerable effort may thereafter be required to obtain the information, see note 14 supra. The cursory nature of the bank's inspection of checks cannot be overemphasized. The banking system currently processes some 30 billion checks per year.

The increasing mechanization of the banking industry continues to reduce the chances that any human agent would come into any direct, significant contact with the underlying transactional information. Prior to the Bank Secrecy Act, the existence of bank microfilms was only a byproduct of the banker's insurance against a lost item-the information contained in the microfilm was rarely of use to the banker. See note 103 supra; Secrecy Act Hearings, supra note 5, at 326-27, 349-50, 357.

This limited use of bank information and the purposes for which the banker gathers data are criteria which readily distinguish bank records from other types of second and third party records. For example, accountants obtain information expressly for use in preparing tax returns: Indeed, much of the information is to be disclosed to the government; cf. Couch v. United States, 409 U.S. 322, 335 (1973). But see United States v. Bremicker, 365 F. Supp. 701, 702-03 (D. Minn. 1973) (bank records considered analogous to accountant's records).

115. See Bank Disclosture Hearings, supra note 3, at 192-200, 228, 263-64; Secrecy Act Hearings, supra note 5, at 313,317-18; 22 U. FLA. L. Rev. 482, 485 (1970). See also Peterson v. Idaho First Nat'I Bank, 83 Idaho 578, 588, 367 P.2d 284, 290 (1961); Tournier v. National Provincial \& Union Bank, [1924] I K.B. 461, 479 (C.A.); N. GoucE, supra note 86 , at $219-20$. The confidentiality of bank transactions is recognized by a number of other countries. See Secrecy Act Hearings 365-68.

116. Listing a bank as a credit reference, however, is considered by most banks to constitute an implied consent to release credit information. R. ChorLey, LAw of BANKING 17, 172 (4th ed. 1960); Interview with Renate Betterton, Credit Manager of the First New Haven Nat'l Bank, in New Haven, Conn., Feb. 19, 1974 .

117. Policies vary from bank to bank, but customary limits on disclosure exist. Upon verification that an inquiry is legitimate, a bank will normally disclose no more than (1) maximum, average, or minimum balance (usually a rough estimate of whichever the bank maintains), (2) the date the account was opened, (3) whether 
actional data usually desired by government agencies are never released to private parties, and breaches of this customary secrecy are rare. ${ }^{118}$ This confidential relationship is supported by more than custom: Banks are under a legal obligation to maintain the secrecy of their depositors' transactions. ${ }^{119}$ Although the duty of secrecy is not unqualified, ${ }^{120}$ the courts have made it clear that the banker functions as an agent in handling account information: He can release data only if consistent with that role. ${ }^{121}$ Thus even without property rights, the depositor has customary and legal rights to control the revelation of checking account information. ${ }^{122}$

Denial of a Fourth Amendment interest leads to the anomalous

the customer's balance at the time of the inquiry is sufficient to meet an existing draft of a specified amount, (4) whether the account has been "satisfactory" or "unsatisfactory." (An "unsatisfactory" evaluation may be subject to provisions of the Fair Credit Reporting Act when used by a consumer reporting agency, see 15 U.S.C. $\$ 2682 \mathrm{~m}(\mathrm{~b})(1970)$.) Interview with Renate Betterton, supra note 116; Interview with Thomas Giaimo, Regional Operations Manager of the Conn. Bank and Trust Co., in New Haven, Conn., Feb. 19, 1974; Interview with William Johnson, Ass't Cashier of the 90 Park Ave. Branch of the Franklin Nat'l Bank, in New York City, Feb. 21, 1974. See also Paton's DIGest $\S 19$, reprinted in Bank Disclosure Hearings, supra note 3 , at 238-57.

118. See 22 U. FLA. L. REv. 482, 485 (1970). See also cases cited in note 115 supra.

119. There have been three cases expressly dealing with liability for disclosure and all found liability to exist. Milohnich v. First Nat'l Bank, 224 So. 2d 759 (Fla. Dist. Ct. App. 1969); Peterson v. Idaho First Nat'l Bank, 83 Idaho 578, 367 P.2d 284 (1961); Tournier v. National Provincial \& Union Bank, [1924] 1 K.B. 461 (C.A.). See also Zimmerman v. Wilson, 81 F.2d 847 (3d Cir. 1936), rev'd, 105 F.2d 583 (1939); Sparks v. Union Trust Co., 256 N.C. 478, 124 S.E.2d 365 (1962); Brex v. Smith, 104 N.J. Eq. 386, 146 A. 34 (Ch. 1929). This duty of secrecy presents a striking contrast to the notion that the bank is somehow a "stranger" to the depositor; cf. Harris v. United States, 413 F.2d 316, 319-20 (9th Cir. 1969).

120. Exceptions to the duty of disclosure exist where the customer consents to a release of information, where the bank must disclose data in its own business interests, e.g., to collect an overdraft, or when a public duty mandates disclosure, i.e., "to prevent fraud or crimes." See Tournier v. National Provincial \& Union Bank, [1924] I K.B. 461, 473, 481 (C.A.); R. CHORLEY, supra note 116, at 16-17.

121. Generally the relationship of bank to depositor is characterized as that of debtor to creditor because of the commercial needs of the banking industry. $R$. CHORLeY, supra note 116 , at 13-22. There is therefore a natural resistance to characterizing the bank's obligations as those of an agent, trustee, or bailee, despite the banking law's incorporation of facets of these relationships. However, for limited purposes of handling account information, the duties of the banker appear to be those of an agent. Peterson v. Idaho First Nat'l Bank, 83 Idaho 578, 586, 367 P.2d 284, 289 (1964), expressly adopted an agency formulation. The exceptions to the duty of secrecy, see note 120 supra, are entirely consistent with the agency status. See RESTATEMENT (SECOND) OF AGENCY \$ 395, Comment $f(1957)$.

122. No case has specifically decided the issue of whether there is a duty of secrecy as to inquiries of government officials. This exception would be somewhat anomalous and justified only by the rationale that the government seeks information for the public welfare and that investigating agents are presumed to adhere to legitimate inquiries; cf. United States v. First Nat'l Bank, 67 F. Supp. 616, 624-25 (S.D. Ala. 1946). But courts, not enforcement agencies themselves, are the institutions which usually balance "public welfare" against those of the individual. See p. 1468 infra. An exception for government officials has never appeared in the few cases on bank secrecy, and in Brex v. Smith, 104 N.J. Eq. 386, 146 A. 34 (Ch. 1929), the court expressly prohibited release of information to a public prosecutor. But cf. Tournicr v. National Provincial \& Union Bank, [1924] 1 K.B. 461, 474 (C.A.) (in illustration of a different point, the court discusses example of a police officer making inquiry to bank without mention of subpoena or bank compliance). 
conclusion that, while safeguarded against all others, the depositor's privacy would be nonexistent when the prying eye belongs to the government. Such a constitutional gap is highly questionable. Checking account records "reveal much about a person's activities, associations, . . beliefs," 123 "political allies, social connections, religious affiliation ... and so on ad infinitum."124 Loss of control over such information would have a substantial adverse impact upon values the Fourth Amendment seeks to preserve. Depositors' control over checking account data is thus a mode of informational control which deserves Fourth Amendment protection surely as much as occupancy of telephone booths.

This conclusion contradicts the holdings of a long line of lower court cases which look exclusively to property relationships in determining depositors' rights in bank records. It is also contrary to Donaldson $v$. United States ${ }^{125}$ if, as several lower court opinions hold, Donaldson is read as restricting the Fourth Amendment to a protection of proprietary interests. But arguably the Supreme Court had no such restrictive intent. The particular result in Donaldson is completely justifiable under the Kalz standard since Donaldson dealt only with routine corporate records involving no expectations of privacy. There is sufficient dictum in the opinion to exempt confidential records from a proprietary interest requirement, which thus allows subsequent courts to apply an "expectation of privacy" analysis to bank records. Nevertheless, the tenor of Donaldson, if not its holding, appears to have hindered the development of Fourth Amendment law. Under Donaldson's shadow neither litigants nor lower federal courts have perceived the implications of Katz $v$. United States in the context of third party records. None of the bank cases which deny depositors' Fourth Amendment interests even mentions "expectations of privacy." ${ }^{26}$ Yet, after two decades of freeing the Fourth Amendment from property law, the Supreme Court does not seem likely to forget Katz and return to property standards. California Bankers Association v. Shultz bears out this contention. Although the majority opinion never reached the issue, five justices argued that depositors may have legitimate expectations of privacy in their bank records. ${ }^{127}$

123. California Bankers Ass'n v. Shultz, 94 S. Ct. 1494, 1526 (1974) (Powell, J., concurring).

124. Id. at 1529 (Douglas, J., dissenting).

125. 400 U.S. 517 (1971). See pp. 1447.50 supra.

126. See cases cited in notes 29 \& 39 supra.

127. "In their full reach, the reports apparently authorized by the open-ended language of the [Bank Secrecy] Act touch upon intimate areas of an individual's personal affairs. . . At some point, governmental intrusion upon these areas would implicate legitimate expectations of privacy." 94 S. Ct. 1494, 1526 (1974) (Powell, J., 


\section{The Bank's Consent to Search}

Even given the existence of depositors' Fourth Amendment interests, an unreasonable search and seizure of bank records would rarely, if ever, take place in the classic manner of breaking, entering, and rummaging through papers: Searches of depositor records are usually conducted with the consent of the bank. ${ }^{128} \mathrm{~A}$ banker's consent -if effective-relinquishes the depositor's privacy and may extinguish any Fourth Amendment claims. The dual issues of authority to consent and voluntariness must therefore be examined.

\section{A. Authority to Consent}

Authority to consent is essentially based upon agency concepts, but in the broad, nontechnical sense of the word "agency" which embraces all informal delegations of authority. Stoner $v$. California, ${ }^{120}$ a leading Supreme Court case, expressly adopted an agency formulation in holding that a hotel's ownership of property (and also its right to have janitors and maids enter guests' rooms for cleaning purposes) was insufficient to give its employees authority to consent to a search of the room rented by the defendant Stoner. The Court looked to delegations of authority from the individual asserting Fourth Amend-

concurring) (joined by Blackmun, J.). "Customers have a constitutionally justifiable expectation of privacy in the documentary details of the financial transactions reflected in their bank accounts." Id. at 1527 (Douglas, J., dissenting). "[T] of a bank, having written or deposited a check, has a reasonable expectation that his check will be examined for bank purposes only-to credit, debit or balance his account-and not recorded and kept on file for several years by Government decree so that it can be available for Government scrutiny." Id. at 1534 (Marshall, J., dissenting). See id, at 1532-33 (Brennan, J., dissenting) (concurs with Justice Douglas' statement on depositor's expectations of privacy).

128. Obtaining records by means of an administrative summons unaccompanied by a judicial enforcement order would technically be with the "consent," or more correctly, the acquiescence, of the bank. The administrative summons, or pocket subpoena, should be distinguished from the judicial subpoena. A bank need not comply with an administrative summons; its only obligation, in the event of noncompliance, is to make its objections known in good faith. Reisman v. Caplin, 375 U.S. 440 (1964), held that sanctions could be imposed for failure to obey an administrative summons only in cases of neglect, default, or contumacious refusal to comply-situations which would be dissipated by an objcction to the summons interposed in good faith. By contrast, compliance with a judicial subpoena is mandatory; accordingly, the process of issuing court subpoenas is surrounded by judicial and adversary safeguards. A judicial subpoena can be issued only by a court and will bear its seal. See FED. R. CIv. P. 45. Prior to issuance of a judicial subpoena enforcing an administrative summons, an adversary hearing will usually be held at which the summoned party can assert his objections. Reisman v. Caplin, supra, at 446. Rule 45 also gives the subpoenaed party the opportunity to interpose objections upon a "motion made promptly."

129. 376 U.S. 483 (1964). Stoner purposely avoided the technicalities and "strained applications of the law of agency" and "unrealistic doctrines of "apparent authority.'" Id. at 488 . 
ment claims. ${ }^{130}$ Stoner implicitly recognizes that property is important only if relevant to authority derived from the individual Fourth Amendment claimant.

To argue that the bank's ownership of documents creates consensual authority misperceives the role of property. The bank's "custody and control" may imply a delegation of authority, but, where unrelated to the individual's privacy involved, property interests do not create an independent right to divulge another's secrets. ${ }^{131}$ If the bank's property rights are significant, it is in negating the expectation of privacy necessary to give rise to depositors' Fourth Amendment interests. But once a court determines that the expectations of privacy are justifiable, property loses independent significance as to the issue of authority to consent. ${ }^{132}$

If presented with the question of divulging checking account records, most bank customers would probably not grant the banker consensual authority. However, a court might conclude that the depositor has given the bank such "complete and unrestricted freedom" over information "that he will be held to have accepted the risk that the [banker] will consent to a search,"133 that is, the depositor may have "implicitly authorize[d] another to consent to an invasion of his privacy."134 Once again, the divergence of property and privacy comes to the foreground. The banker has complete physical control of records, which in other contexts might conclusively demonstrate con-

130. It is important to bear in mind that it was petitioner's constitutional right which was at stake here, and not the night clerk's nor the hotel's. It was a right which only the petitioner could waive by word or deed, either directly or through an agent.

Id. at 489.

131. See Chapman v. United States, 365 U.S. 610 (1961) (even though landlord accompanied officers making search of tenant's premises, landlord's consent, based on clause in lease which gave him right to enter premises for purpose of viewing waste, was ineffective); United States v. Jeffers, 342 U.S. 48 (1951) (assistant hotel manager could not give consent to search guest's room, despite guests" "implied or express permission" to permit "such persons as maids, janitors, or repairmen" to enter room "in the performance of their duties"); Corngold v. United States, 367 F.2d 1 (9th Cir. 1966) (freight carrier could not consent to search and seizure of package given it for shipment, despite clause in tariff which authorized the carrier to open it for inspection, if necessary); Holzhey v. United States, 223 F.2d 823 (5th Cir. 1955) (landlord's control of premises not sufficient to give consent to police to pry open tenant's locked cabinet); United States v. Blok, 188 F.2d 1019 (D.C. Cir. 1951) (employer not authorized to consent to search of private parts of its desk used by employee); Bielicki v. Superior Court, 157 Cal. 2d 602, 371 P.2d 288, 21 Cal. Rptr. 522 (1962) (no effective consent to search where owner of amusement park agreed to police installation of pipe which would enable police to view homosexual activities in pay toilet stalls).

132. In Stoner and each of the cases cited in note 131 supra, the second or third party's property interest was insufficient to grant it independent consensual au thority once the courts determined that the Fourth Amendment interests (i.e., justifiable expectations of privacy) were present.

133. Corngold v. United States, 367 F.2d 1, 7 (9th Cir. 1966).

134. Id. 
sensual authority. However, in dealing with the information contained in those records, the banker actually has very little freedom: $\mathrm{He}$ is bound by a legal duty of secrecy at least as to private parties. The limitations ordinarily accompanying the banker's disclosure of account data thus negate any attempt to imply customer authorization and the customer's control remains paramount. ${ }^{135}$ In the context of a highly regulated and institutionalized industry with a tradition of customer secrecy, there is no common sense notion that a bank's access to information carries with it the authority to invade depositors' privacy, or that the customer necessarily accepts such a risk. Since the government bears the burden of proof in demonstrating valid consent, ${ }^{136}$ the ambiguity-at a minimum-regarding the bank's authority would probably render the search unreasonable.

Recognition of a banker's power to consent is also unwise for several policy reasons. Most consent searches involve an agent who is related to and aware of at least some of the principal's interests. ${ }^{137}$ Bankers who release customer records may not even know the depositor, let alone be able to assess his particular desire for privacy. With broad authority over thousands of accounts, the banker, in allowing searches of checking accounts, preempts the neutral, detached magistrate. It is the banker then who frequently balances the needs of law enforcement agencies against the privacy interests of a depositor. Courts have been extremely reluctant to place such power or decisions in nonjudicial hands. ${ }^{138}$ The banker is ill-equipped to perform this quasi-judicial role: He may yield too quickly to unsupported allegations of "national security," or he may simply acquiesce to avoid the bother of the whole affair. ${ }^{139}$ Since such extraneous factors may affect

135. Compare id., with United States v. Avercll, 296 F. Supp. 1004 (E.D.N.Y. 1969). 136. See Bumper v. North Carolina, 391 U.S. 543 (1968). See also Schneckloth v. Bustamonte, 412 U.S. 218 (1973).

137. But cf. Note, Third Parly Consent: An Alternative Analysis, 41 U. CHr. L. Rev. $121,122-23$ (1973).

138. See United States v. United States Dist. Court, 407 U.S. 297, 314-18 (1972) (neutral magistrate, not mere say-so of U.S. Attorney General, required for issuance of a lawful wiretapping order); Coolidge v. New Hampshire, 403 U.S. 443, 449.55 (1971) (state attorney general, as person in charge of the investigation and ultimate prosecution, was not sufficiently neutral to determine whether warrant should issue); Johnson v. United States, 333 U.S. 10, 14-15 (1948) (search of hotel room on police officer's apparently reasonable suspicion illegal on grounds that absent exceptional circumstances, "a magistrate's warrant for search may not be dispensed with"). See also Fuentes v. Shevin, 407 U.S. 67 (1971) (writ of replevin may not issue without opportunity for a judicial, adversary hearing); Bank Disclosure Hearings, supra note 3, at 46; cf. California Bankers Ass'n v. Shultz, 94 S. Ct. 1494, 1526 (1974) (Powell, J., concurring) ("the potential for abuse is particularly acute where, as here, the legislative scheme permits access to this information without invocation of the judicial process").

139. The banking community itself does not desire to assume the responsibility of these decisions. See Bank Disclosure Hearings, supra note 3 , at 228-29. 
the banker's decision, the depositor's Fourth Amendment interests would be subject to the vagaries and potential inequities of the banker's political and social views.

\section{B. Public Duty Disclosure}

There exists a limited number of instances where the bank may disclose customer records based on a "public duty" exception to its obligation of secrecy. This exception, which is not dependent on a theory of consent, ${ }^{140}$ was formulated in dictum in Tournier $v . \mathrm{Na}$ tional Provincial \& Union Bank. ${ }^{141}$ The duty appears to be simply the civil obligation of any agent who of his own initiative discovers an illegality. ${ }^{142}$ Being the only party aware of the offense, the banker must inform authorities if further crime and fraud are to be prevented. However, this duty applies only if the bank itself discovers the illegal act ${ }^{143}-$ an increasingly unlikely event as the number and mechanization of bank transactions expand. ${ }^{144}$ Where authorities already know of suspect activities and can utilize judicial process and other lawful means to investigate, the banker's public duty is no longer paramount when juxtaposed with customer obligations. The possibility that authorities may attempt to deny to depositors Fourth

140. An individual always assumes the risk that an employee or agent performing his duties may expose an illegality to proper authorities. See United States v. White, 401 U.S. 745 (1971). Fourth Amendment protection covers an agency relationship which ambodies informational control only to the extent that the agent is limited in his freedom to disseminate the information. No agent is cver bound to keep a discovered illegality secret. See Restatement (SECOND) of AGENCY $\$ 395$ (1957). When an agent discovers illegal conduct, his principal has no right to control the agent's dissemination of that particular information. In his relationship with the agent involving that specific information, the principal no longer has the control which would give rise to justifiable expectations of privacy.

141. [1924] 1 K.B. 461 (C.A.).

142. Id. at 473 .

143. Cf. R. Chori.ey, supra note 116 , at 17 (the public duty exception to confidentiality between bank and depositor exists, as one example, where a bank finds a customer trading with the enemy in time of war). Apparently, "public duty" has never been described as either obligating or authorizing a bank to accede to police requests or to provide private papers to substantiate government suspicions concerning depositors.

Note that a distinctly different "duty of cooperation" is occasionally mentioned in American court opinions. This "duty of cooperation" generally refers to a bank's obligation to expend a reasonable effort (of both time and expense) in furnishing records needed in judicial proceedings or in attempting to comply with a court subpoena. See United States v. Dauphin Trust Co., 385 F.2d 129, 130 (3d Cir. 1967); McMann v. SEC, 87 F.2d 377 (2d Cir.), cert. denied, 301 U.S. 684 (1937); United States v. Jones, 73-1 U.S. Tax Cas. 9197 (M.D. AJa., Oct. 6, 1972); United States v. First Nat'l Bank of Mobile, 67 F. Supp. 616, 625 (S.D. Ala. 1946). But see United States v. Bremicker, 365 F. Supp. 701, 703 (D. Minn. 1973) ("it would appear that a bank [served with an IRS summons] has a duty to cooperate [through full compliance:], even in the absence of a court order ..."). This "duty of cooperation" is often coupled with qualifications concerning the customer's rights. See, e.g., Cooley v. Bergin, 27 F.2d 930, 933 (D. Mass. 1928).

144. See generally p. 1442, notes 88 \& 107 supra. 
Amendment protection by "advising" bankers to be wary of certain depositors suggests that the public duty exception be interpreted narrowly.

\section{Voluntariness of Consent}

The use of administrative summons to obtain bank records raises doubts concerning the bank's voluntariness in giving consent. Many bankers are unaware that an administrative summons carries no enforcement authority and may be resisted. ${ }^{145}$ Their acquiescence to an administrative search is thus often the result of apparent coercion. Whether a banker's acquiescence is sufficiently "voluntary" so as to render the search of bank records reasonable, however, lies on the uncertain ground between two major Supreme Court cases. Bumper v. North Carolina ${ }^{146}$ held that consent to search given by a homeowner was invalid when police stated that they possessed a search warrant and implied that they would search the premises in any case. Evidence obtained in the search was excluded as fruits of an illegal seizure. On the other hand, Schneckloth v. Bustamonte ${ }^{147}$ held that the state, in demonstrating valid consent, need not prove the claimant's knowledge of a right to refuse permission to search, ${ }^{148}$ and in dicta indicated that consent might be valid even given total absence of such knowledge. ${ }^{149}$ Unless Schneckloth is read to imply that knowledge of a right to refuse is irrelevant, it would appear that a depositor who could prove that his banker did in fact reasonably believe that he had no right to refuse the summons would succeed in invalidating the search.

The validity and authority of the bank's consent may thus prove nonexistent and therefore not relinquish the individual's Fourth Amendment interest. However, consent is also an issue which bears upon the enforcement of the Fourth Amendment through the exclusionary rule. Even though a search is without effective consent (and, absent a warrant, "unreasonable" according to an objective balancing

145. The President of the American Bankers Association, Rex Morthland, stated, When [an administrative summons] had been issued and presented properly, I don't know of any cases where it has been resisted. I hasten to add however, that there is a lack of knowledge on the part of bankers that they can legally resist such a [summons]. . . I I try to study these things a little more diligently than most people, but it was only a few years ago that I knew I could resist such an administrative summons.

Bank Disclosure Hearings, supra note 3, at 232.

146. 391 U.S. 543 (1968).

147. 412 U.S. 218 (1973)

148. Id. at $232,234,248-49$.

149. Id. at 234 . 
of police needs and privacy), evidence may nonetheless be admitted if the actual police behavior was reasonable under the circumstances. ${ }^{150}$ Notwithstanding the unreasonableness of the search, exclusion as a means of deterrence would, in such a case, have no effect. ${ }^{151}$ This consideration may weigh against retroactive evidentiary exclusion where police justifiably believed that their actions were within the limits of the law as then pronounced. Yet, once the depositor's Fourth Amendment interest in bank records is known, exclusion as a deterrence measure would be justified.

\section{Reconciling Fourth Amendment Interests With Police Needs}

Recognition of depositors' Fourth Amendment interests in checking account records will likely be resisted on grounds of law enforcement needs. The Fourth Amendment implicitly recognizes these needs by forbidding only unreasonable searches. It is here, in the assessment of "unreasonable searches and seizures," that police claims must be balanced against the protection given the individual's privacy. By contrast, the initial determination of Fourth Amendment interests depends only upon the strength of the privacy interest involved, i.e., the presence of "justified expectations of privacy," a factor in which law enforcement requirements bear little relevance. Whether Fourth Amendment interests exist is a question only of identifying the subject matter to be protected, not a matter of balancing the protection given against the interests of police authority. ${ }^{152}$ These two distinct processes should not be confused. If reasonableness criteria such as

150. Examination of police behavior to determine whether Fourth Amendment sanctions should be invoked is clearly seen in United States v. Roberts, 223 F. Supp. 49 (E.D. Ark. 1963), aff'd, 392 F.2d 892 (8th Cir. 1964), cert. denied, 380 U.S. 980 (1965). The court, however, mistakenly perceives its analysis as going to the validity of consent and the objective reasonableness of the search rather than to the exclusionary issue. Perhaps this is due to a judicial reluctance to admit that evidence obtained in an "unreasonable" search is not necessarily excluded.

151. The inapplicability of the exclusionary rule despite the existence of an unreasonable search is best illustrated in a hypothetical example. Assume that while $B$ is burglarizing $A$ 's home, police come to the door. Having no choice other than running and surely entailing chase, $B$ decides to answer the door and act the part of a resident. When $B$ greets the police, he is informed that they are undertaking an investigation of $A$ and would like to search the premises. Representing himself as a cotenant, $B$ invites the police to search. Evidence incriminating $A$ is discovered in common areas of the house. Later, $A$ is arrested and charged on the basis of this evidence. Still later, $B$ is captured and will testify to all the events. Despite the invalidity of the consent and therefore the objective unreasonableness of the search not conducted pursuant to a warrant, evidence may not be excluded since, under the circumstances, the actual police behavior was reasonable; cf. Roberts v. United States, 223 F. Supp. 49 (E.D. Ark. 1963), aff'd, 332 F.2d 892 (8th Cir. 1964), cert. denied, 380 U.S. 980 (1965).

152. See generally Note, The Concept of Privacy and the Fourth Amendment, 6 U. MICH. J.L. REFORM 154, 179-80 (1972). 
"probable cause" 153 or enforcement methods such as the exclusionary rule ${ }^{154}$ are defective or unfair, these problems should forthrightly be considered on their own terms and in their own sphere and not allowed to distort the nature of Fourth Amendment interests. ${ }^{155}$

The Court in California Bankers Association v. Shultz never assessed the reasonableness of government access to bank microfilms, and commented only that access was "controlled by existing legal process." Absent the depositor's Fourth Amendment interest in bank records, however, "legal process" may amount to nothing more than bank acquiescence to government surveillance. ${ }^{157}$

Only recognition of a Fourth Amendment interest in checking account records endows "legal process" with substantive meaning outside the context of administrative subpoenas. ${ }^{158}$ Assuming that current standards for determining the reasonableness of searches remain unchanged, the Fourth Amendment should protect depositors against examinations of bank records conducted without judicial supervision or without the depositor's consent. ${ }^{150}$ The standards of reasonableness

153. The Supreme Court has insisted upon "probable cause as a minimum requirement for a reasonable search" and has declared searches without warrants "per se unreasonable" unless they fall within "a carefully defined set of exceptions based on the presence of 'exigent circumstances." Chambers v. Maroney, 399 U.S. 42, 51 (1969). See also Coolidge v. New Hampshire, 403 U.S. 443, 474-75 (1971); T. TAYLoR, Two STUDIES IN CoNSTITUTIONAL INTERPRETATION 23-24, 39-44 (1969).

154. For recent comment, see, e.g., Bivens v. Six Unknown Named Agents of the Federal Bureau of Narcotics, 403 U.S. 388, $411-27$ (1971) (Burger, C.J., dissenting); Oaks, Studying the Exclusionary Rule in Search and Seizure, 37 U. CHI. L. REv. 665 (1970),

155. Criteria for determining the existence of Fourth Amendment interests and for "reasonable" searches have on occasion been mixed together. Recent opinions may have embraced an expansive view of the Fourth Amendment's scope by erroneously relying on the relative impropriety of the police behavior involved-factors that have little to do with the privacy interest protected. See United States v. White, 401 U.S. 745, 786 (1971) (Harlan, J., dissenting); People v. Krivda, 5 Cal. 3d 357, 486 P.2d 1262, 96 Cal. Rptr. 62 (1971), vacated and remanded per curiam, 409 U.S. 33 (1972), aff'd on rehearing, 8 Cal. 3d 623, 504 P.2d 457, 105 Cal. Rptr. 521, cert. denied, 412 U.S. 919 (1973); People v. Edwards, 71 Cal. 2d 1096, 458 P.2d 713, 80 Cal. Rptr. 633 (1969).

A radical proposal for interpreting the Fourth Amendment, Judge Hufstedler's, would abandon all limits upon Fourth Amendment interests and would consider all govern. ment activities as searches of the individual's person. Extremely flexible criteria would be used to evaluate the reasonableness of the search and seizure. See Hufstedler, supra note 81, at 561-62. While courts to a limited extent adjust reasonableness criteria to the subject of the search and seizure (see Roaden v. Kentucky, 413 U.S. 496, 501-06 (1973)), Judge Hufstedler's infinite expansion of Fourth Amendment interests is at this point only an academic, though intriguing, proposal.

156. California Bankers Ass'n v. Shultz, 94 S. Ct. 1494, 1513 (1974).

157. See id. at 1535 (Marshall, J., dissenting).

158. Where the government attempts to obtain bank records through judicial en. forcement of an administrative summons, a court may permit a depositor to intervene in proper circumstances to contest a wrongful use of the summons or raise objections at a later trial. See Donaldson v. United States, 400 U.S. 517 (1971).

159. There are a few instances where the Fourth Amendment does not proscribe a search of the depositor's accounts. Audits by bank examiners and other inspections necessary for regulation of the banking industry are clearly permissible as "reasonable," even if deemed "searches" of the depositor. The Supreme Court has approved warrantless searches where necessary for the supervision of government regulated busi- 
applicable to a particular search vary with the type of access attempted. ${ }^{160}$ A full-blown ex parte search and seizure would be considered unreasonable unless pursuant to a warrant or justified by exigent circumstances; probable cause would of course be necessary. ${ }^{161}$ While the standard of probable cause need not be met when documents are compelled by administrative or grand jury subpoenas, judicial supervision and other constitutional safeguards would still be present. ${ }^{102}$ Since banks lack authority to consent to a search or relin-

ness. See United States v. Biswell, 406 U.S. 311, 316 (1972); Colonnade Catering Corp. v. United States, 397 U.S. 72 (1970). See also Almeida-Sanchez v. United States, 413 U.S. 266, 271 (1973); Youghioheny \& Ohio Coal Co. v. Morton, 364 F. Supp. 45 (S.D. Ohio 1973). The burdens of bank audits are clearly necessary for the maintenance of a sound banking system, and in the terminology of Almeida-Sanchez $v$. United States, supra, at 271, depositors must "accept the burdens as well as the benefits" of the banking system. Use of the banking system implies a consent to searches reasonably necessary for the system's maintenance. Also, information concerning the depositor is not a focus of, and is generally extraneous to, the examiners' inquiry. See also United States v. Dauphin Deposit Trust Co., 385 F.2d 129, 131 n.2 (3d Cir. 1967); United States v. First Nat'l Bank of Mobile, 67 F. Supp. 616 (S.D. Ala. 1946); Cooley v. Bergin, 27 F.2d 930, 932 (D. Mass. 1928). Fourth Amendment interestswhich are dependent upon "justified expectations of privacy" generated by the bank's role as a passive intermediary-would not prevent searches, or exclude their fruits, when occasioned by the bank's statts as the depositor's agent, e.g., investigations of forged, altered, or stolen items or of embezzlement directly concerning the bank in its relationship with the depositor.

160. The Bank Secrecy Act and the Treasury regulations promulgated thereunder provide for an additional means of government access to bank information-required reports of depositor transactions. See note 52 supra. These reporting requirements are discussed in more detail in California Bankers Ass'n v. Shultz, 94 S. Ct. 1494, 1505-07 (1974). There the reporting requirements were upheld as to the banks, without reaching any possible claims the depositors might have under the Fourth or Fifth Amendments as to the domestic reporting requirements. Id. at 1518-24. The Court rejected depositors' Fourth Amendment objections to the foreign transaction reports. Id. at $1516 \cdot 18$.

161. See note 153 supra.

162. Probable cause is not required for issuance and cnforcement of an administrative subpoena. United States v. DeGrosa, 405 F.2d 926, 929 (3d Cir.), cert. denied, 394 U.S. $973(1969)$. Administrative subpoenas are generally upheld if: (1) the underlying investigation has a legitimate civil purpose and is authorized by Congress; (2) the documents sought are relevant and material to the investigation; (3) the subpoena is sufficiently specific so that compliance will not be unreasonably burdensome; (4) procedural requirements are met. See United States v. Powell, 379 U.S. 48, 57-58 (1964); United States v. Morton Salt Co., 338 U.S. 632, 652-53 (1950); Oklahoma Press Publishing Co. v. Walling, 327 U.S. 186, 208-11 (1946); FTC v. American Tobacco Co., 261 U.S. 298, 305-07 (1924); United States v. DeGrosa, supra. See also Donaldson v. United States, 400 U.S. 517, 530-36 (1971) (subpoena may not be used in support of an ongoing criminal prosecution); Bisceglia v. United States, 486 F.2d 706 (6th Cir. 1973), cert. granted, 42 U.S.L.W. 3584 (1974) (IRS subpoena for bank records held unauthorized when no specific taxpayer has been identified as the subject of the investigation); United States v. Theodore, 479 F.2d 749 (4th Cir. 1973) (accord with Bisceglia).

The requirement of a civil purpose for issuance of an administrative subpoena has recently been criticized. See, e.g., United States v. Ruggerio, 300 F. Supp. 968 (C.D. Cal.), aff'd, 425 F.2d 1069 (9th Cir. 1969), cert. denied, 401 U.S. 922 (1971) (in tax investigations some civil purpose is always present; Fourth Amendment merely forbids use of subpoenas for criminal prosecution in esse). See generally Donaldson v. United States, 400 U.S. 517, 532-33 (1971); Reisman v. Caplin, 375 U.S. 440, 449 (1964). Justice Douglas's concurrence in Donaldson, which was quoted in California Bankers Ass'n v. Shultz, 94 S. Ct. 1494, 1513 (1974), implies that administrative subpoenas may be 
quish records, an administrative summons delivered to the bank should not be permitted to undercut the depositor's rights. ${ }^{103}$

\section{Conclusion}

Bank depositors' privacy can perhaps be guaranteed to some extent through a number of ad hoc legal doctrines, including a propertyoriented Fourth Amendment. But a more important task suggested by a desire to protect that privacy is to conceptualize Fourth Amendment interests in terms more appropriate to a technological society in which property and privacy are no longer unified. The Supreme Court has already left behind the technicalities of property law and has charted a broad construction of Fourth Amendment interests based upon "expectations of privacy." This Note has maintained that bank depositors' expectations of privacy with regard to their personal checking account records are justified: Not only is a high degree of individual informational control desirable; it is supported by customary norms, practices, and legal constraints. If the safeguards envisioned by the Amendment's drafters are to remain viable, the Fourth Amendment can demand no less than protection of these expectations of privacy from the prying eye of the government.

utilized even to obtain evidence solely for criminal prosecutions. See Donaldson v. United States, supra, at 537 (Douglas, J., concurring).

In the case of grand jury subpoenas probable cause is not required, but some demonstration of reasonableness is necessary. In re September, 1971, Grand Jury, 454 F.2d 580 (7th Cir. 1971), rev'd sub nom. United States v. Mara, 410 U.S. 19 (1973); In re Dionisio, 442 F.2d 276 (7th Cir. 1971), rev'd sub nom. United States v. Dionisio, 410 U.S. 1 (1973). The standards of reasonableness, however, remain unclear. September, 1971, Grand Jury called for an adversary hearing and adopted standards similar to those applicable to administrative searches. $45 \pm$ F.2d at 584-85. The Seventh Circuit opinion in Dionisio noted that "the grand jury is not required to have a factual basis for commencing an investigation and can pursue rumors and clues which further investigation may prove groundless." 442 F.2d at 281. See also 410 U.S. at I5. The Supreme Court reversed both decisions, holding that a subpoena of voice and hand. writing exemplars was not a seizure under the Fourth Amendment. 410 U.S. at 15, 22. See also United States v. Calandra, 94 S. Ct. 613, 618-19 (1974). See generally Hannah v. Larche, 363 U.S. 420, 449 (1960); In re Grand Jury Proceedings, 486 F.2d 85, 91 (3d Cir. 1973).

163. See note 128 supra for a discussion of the differences between an administrative summons and a judicial subpoena. A bank would still have to respond to the administrative summons, although its response may be merely to state that it has no consensual authority to release the records. 